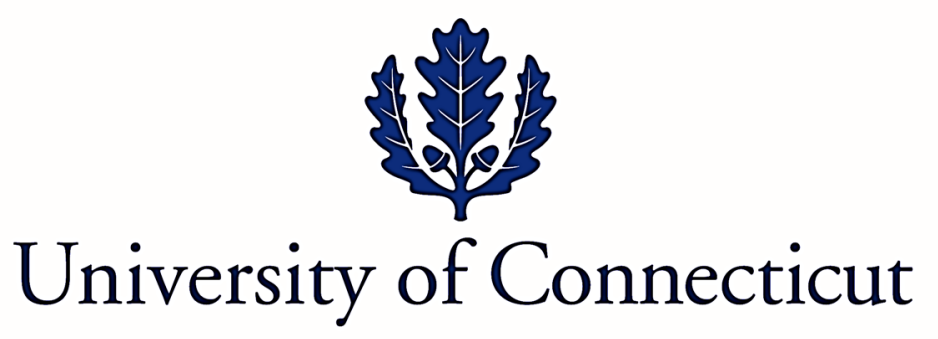

Department of Economics Working Paper Series

\title{
The Impact of Health on Wealth: Empirical Evidence
}

by

Umesh Ghimire

University of Connecticut

Working Paper 2020-19

December 2020

365 Fairfield Way, Unit 1063

Storrs, CT 06269-1063

Phone: (860) 486-3022

Fax: (860) 486-4463

http://www.econ.uconn.edu/

This working paper is indexed in RePEc, http://repec.org 


\title{
The Impact of Health on Wealth: Empirical Evidence*
}

\author{
Umesh Ghimire $^{\dagger}$
}

December 23, 2020

\begin{abstract}
This paper empirically evaluates the impact of health on wealth. Using the frailty index as a measure of health and carefully accounting for the dynamic relationship between frailty and wealth, I find that suffering one more health deficit leads, on average, to a 2.45 percent decline in the household net worth of individuals between age 50 and 100. The household net worth of individuals with no college degree, poor health, and over the age of 70 is significantly negatively affected by poor health. The results pass the tests of instrument validity and are consistent across several alternative definitions of wealth. Using financial net worth as a definition of wealth, I find that the average impact of frailty on wealth is the largest, while it is the smallest when wealth is defined to include only housing net worth.
\end{abstract}

JEL classification: D31, I140

Keywords: Wealth, Health

*I am indebted to my advisor Kai (Jackie) Zhao for his guidance and mentorship throughout this project. This work would not have been possible without his support. All errors are mine.

${ }^{\dagger}$ Economics Department, University of Connecticut, 365 Fairfield Way, U-1063 Storrs, CT 06269-1063 (email: umesh.ghimire@uconn.edu). 


\section{Introduction}

The empirical relation between health and wealth has been an issue of increasing academic and policy interest. While there exists literature that studies the relationship between socioeconomic status and health, this paper aims to examine the impact of health on wealth, accounting for their dynamic relationship, which has not been explored well. In doing so, the paper adopts a new measure of health, the frailty index 1 . Frailty index is a continuous measure of health that allows me to account for the effect of finer variations in health on wealth. Studies on the impact of health on wealth focus either only on the retirees (Wallace, Haveman, and Wolfe (2017), Wu (2003)) or use a narrow measure of health. The impact of health on wealth has been extensively studied in the quantitative macroeconomics literature (see Palumbo (1999), De Nardi, French, and Jones (2010), De Nardi, Pashchenko, and Porapakkarm (2017), Nakajima, Telyukova, et al. (2018), Kopecky and Koreshkova (2014), Zhao (2014), Zhao (2015) etc.). I document the empirical relationship between health and wealth using data from the Health and Retirement Study (HRS) covering eight waves of panel data (from 2000 to 2014)2 As shown in Figure 1, healthier individuals tend to be wealthier. This fact is independent of the health measure I use. For instance, I use two different measures of health and plot the average household wealth by age across health distribution. Wealth differences across health distribution appear similar. In panel (a) of Figure 1, I construct five health groups and plot the average wealth by age for each group. In panel (b), I do so by the individual's subjective rating of health as available from the survey data ${ }^{3}$. It appears from Figure 1 that health and wealth are correlated. My objective is to empirically evaluate

1. Following Hosseini, Kopecky, and Zhao (2019a), I construct the frailty index as a measure of health status used in this paper. Throughout, I use health and frailty interchangeably. I will discuss in detail the construction of the frailty index in the next section. One of the advantages of the frailty index is that it is a continuous variable, unlike the subjective rating of health status. I will also define the concept of wealth in the next section.

2. Please see the next section for a detailed explanation of sample selection.

3. The use of subjective rating of health in panel (b) is only to illustrate the point that wealth differentials by health are independent of the measure of health I use. I do not use subjective health status in this analysis. 
the marginal effect of change in health on wealth.

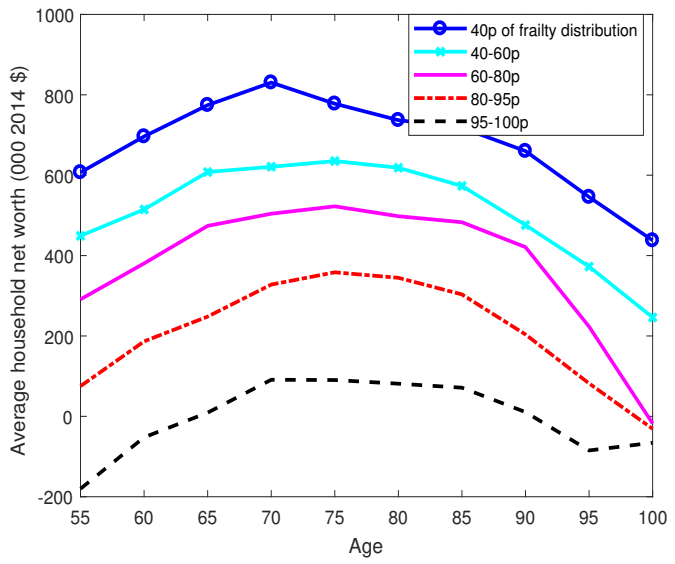

(a)

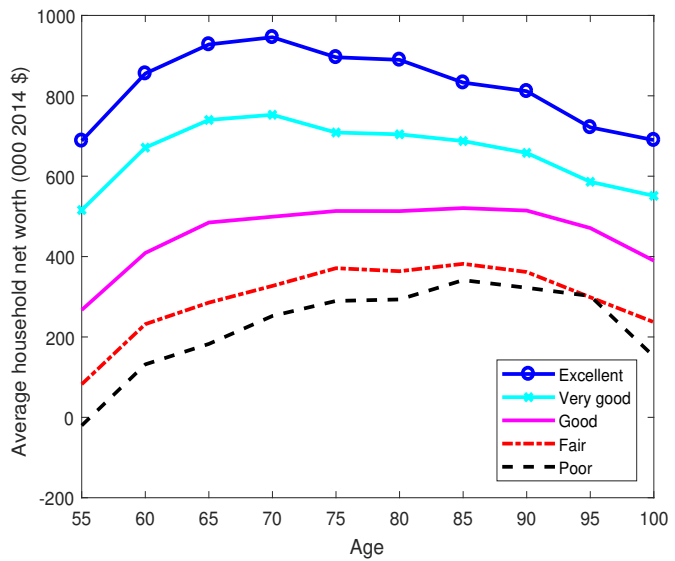

(b)

Figure 1: Panel (a) average household net worth by frailty, panel (b) average household net worth by self-reported health status. These are averages for the five year age groups in 2014. For example, age 55 in the graph represents average for the age group 50-55. $40 p$ refers to $0-40$ percent. Data source: Health and Retirement Study (HRS) 2000-2014.

This paper is related to a number of studies that have attempted to evaluate the empirical relationship between wealth and health. Smith (1999) uses PSID, HRS, and AHEAD data to assess the impact of health shock on wealth. He concludes that health shocks reduce household wealth among the American elderly (age 70 or older). He shows that the severity of health shock increases wealth loss. Smith $(2004)$ assesses the connection between the socioeconomic status (measured by household income and household wealth) using PSID and the HRS data. He concludes that the effect of health on socioeconomic status is quantitatively important. While he finds that household wealth and individual health outcomes unrelated, the impact of education on health outcomes is significant. He also finds that the socioeconomic status during childhood (including parental income) is also quantitatively important for explaining health outcomes later in life. I am interested in the impact of health on household wealth. My approach emphasizes the importance of accounting for the dynamic relationship between health and wealth, which is missing from these studies. Coile and Milligan (2009) argue that household wealth portfolio is affected by health shocks as 
individuals age. Using the HRS data, they show that households increase the proportion of wealth on liquid assets and reduce the proportion of wealth on assets such as real estate, vehicles, and businesses as they age. They argue that the effect of health shock is larger among individuals with physical or mental health limitations. Wallace et al. (2012) follow the retirees in the HRS data for a decade to assess how shocks the physical and mental health affects their annuitized net wealth during those years. They find that negative shocks to physical and mental health during early retirement have a significant effect. Since they focus on early retirees, they potentially miss larger effects of poor health during later ages. My analysis is based on the sample of individuals aged 50 and 100, which I believe is better suited not only to evaluate the average effect of health on wealth but also to understand how poor health affects retired and not-retired individuals differently. I find that poor health significantly negatively affects retirees and has no significant effect on non-retirees. In addition, the elderly (above age 70) are also significantly negatively affected by poor health.

Using the dynamic panel data approach, Wallace, Haveman, and Wolfe (2017) assess the short-run and long-run effects of health shocks on the wealth of the married retiree couples. They find that health shocks could lead to a significant wealth decline of the retirees in the long run (over a period of 10 years). I differ from their analysis in several ways. First, their emphasis is on assessing whether retirees have adequate assets during retirement, while I focus on the overall impact of health on wealth among retirees and working people. I estimate the average impact of suffering one more health deficit on wealth. This analysis uses more comprehensive data in the sense that it contains information on all individuals aged 50 or above, married or unmarried. It allows us to evaluate the impact of health on wealth both before and after retirement. In fact, I find that bad health has a significant effect on the wealth of the retirees and an insignificant effect on the wealth of individuals who have not retired. Second, I adopt a more comprehensive measure of health as developed by Hosseini, Kopecky, and Zhao (2019a) than the one used by Wallace, Haveman, and Wolfe (2017) as I use 36 different health conditions as opposed to their 21 conditions. Wallace, Haveman, 
and Wolfe (2017) rely only on the measures of physical health, while I use the measures of physical as well as cognitive health in the health index I use. A more comprehensive measure of health is important to accurately measure the average effect of one more health deficit on wealth. Third, their analysis is based on waves 2 through 10 of HRS data on just one cohort (the HRS cohort). The data I use is more comprehensive as I use data on all the cohorts included in the survey (more on this in the next section). Focusing only on married couples nearing retirement, $\mathrm{Wu}(2003)$ finds that shocks to the health of wife have a significant effect on household wealth while the effect of shocks to husband's health have an insignificant effect. Using a latent health index based on 28 different health conditions, Poterba, Venti, and Wise (2011) find that the evolution of assets is correlated with health status. They do not, however, estimate the impact of health status on wealth.

My main contribution is to estimate the average impact of suffering one more health deficit (to be defined in the next section). I find that suffering one more health deficit leads to a 2.45 percent decline in total household net worth. This decline varies across groups with different education, health, age, and retirement status. Results show that the impact of health on wealth among the non-retirees, those younger than 70, those with a college degree, and those in the bottom 80 percent of the frailty distribution is insignificant. In contrast, the impact among the retirees, those aged 70 years or above, without a college degree, and in the top 20 percent of the frailty distribution is significantly negative. The impact of frailty on wealth also differs by the type of wealth under consideration. For example, I find that the effect of frailty is largest on financial wealth and smallest on housing wealth. To my knowledge, there is no prior published work analyzing the impact of health on wealth accounting for the dynamic relationship between health, wealth, and other socioeconomic factors affecting both health and wealth.

4. Most of the related works are either focused only on one specific group (such as married, retired, or their combination) or are merely interested in evaluating how health and wealth evolve over time. 


\section{Data and summary statistics}

I use wave 5 through 12 of the RAND HRS data for the analysis 5 The HRS panel survey is run every two years. The HRS has detailed information on the health, income, wealth of respondents aged 50 years or older and their spouse of any age. Since the number of individuals below age 50 is small, I use data on individuals aged 50 to 100 years. I drop the first four waves of the data because the wealth data in the early waves of the HRS survey are inaccurate (Rohwedder, Haider, and Hurd (2006)). In addition, data on the secondary house is missing in wave 3. Starting the 2002 wave of the survey, the HRS took measures to improve the accuracy of wealth data (Hurd et al. (2016)). This included, among other questions, asking respondents about the accuracy of the wealth numbers reported in the

previous wave, allowing HRS to reduce erroneous variation in wealth data over time. As a result, wealth measures have improved. The first wave in the sample is 2000, and the last is 2014 (for a total of eight waves). The data file I use contains information about six cohorts based on their birth year: (1) The Asset and Health Dynamics Among the Oldest Old (AHEAD) cohort (born before 1924), (2) the Children of Depression (CODA) cohort (born 1924-1930), (3) the Health and Retirement Study (HRS) cohort (born 1931-1941), (4) the War Babies (WB) cohort (born 1942-1947), (5) the Early Baby Boomers (EBB) cohort (born 1948-1953), and (6) the Mid Baby Boomer (MBB) cohort (born 1954-1959). The EBB cohort entered the survey beginning the 2000 wave, and the MBB cohort entered the survey beginning the 2004 wave of the survey. All other cohorts were interviewed in all the waves the paper uses.

\subsection{Measure of wealth}

The HRS reports wealth at the household level. I use the concept of net worth as wealth (taken from the HRS data), defined as follows:

5. I use the RAND HRS Longitudinal File 2014 (V2) for the analysis. 
Net worth $=$ housing + vehicles + business + IRA + stocks + savings and checking deposits + certificate of deposits $(\mathrm{CD})+$ bonds + other wealth - mortgage - home loan other debt - other mortgages.

\section{$2.2 \quad$ Frailty index}

Following Hosseini, Kopecky, and Zhao (2019a), I construct a frailty index to measure health. Throughout the paper, I use frailty and health interchangeably. The frailty index is a summary of the extent to which an individual suffers from health deficits. A health deficit is a condition that worsens health. It could be memory loss, high blood pressure, cancer, inability to carry out activities of daily living (ADL), or obesity. I take 36 different health conditions (deficits) from the HRS data to construct the frailty index, which

Frailty index $=\frac{\text { Number of deficits present }}{\text { Total number of deficits considered }}$.

For instance, an individual with 5 of the 36 deficits would have frailty index $=\frac{5}{36}=0.14$. This objective measure of health is based on the 36 different health deficits (Table 10), on which the data is available in the HRS data. The average frailty increases with age and decreases with education (Figure 2).

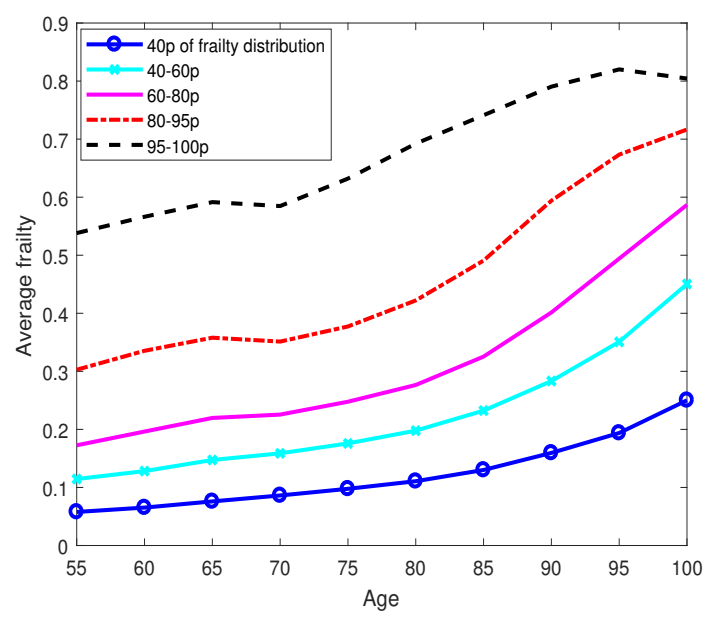

(a)

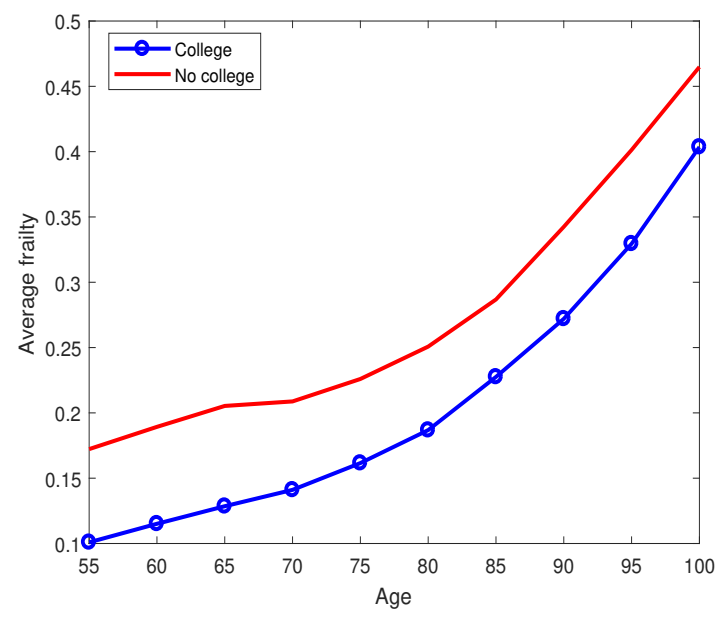

(b)

Figure 2: Panel (a): average frailty by frailty category, panel (b) average frailty by education level. (Data source: HRS 2000-2014) 
Table 1 presents the descriptive statistics of the working sample. I drop the observations if household net worth or household net income is non-positive. Table 1 shows that healthier and better educated households have higher average net worth and income. The net worth and household income values are expressed in 2014 U.S. Dollars using the consumer price index available from the Federal Reserve Bank of St. Louis. Observe that the least frail 80 percent of households hold more than double the net worth the most frail 20 percent of the households. The household income differences are similar. On the other hand, unhealthiest 20 percent have average frailty nearly thrice the frailty healthiest 80 percent of households have. The standard deviation of frailty is also higher among the households in the unhealthiest 20 percent group. The wealth and income differences are even large by education. On average, the household net worth of college-educated individuals is 2.77 times as high as those without a college degree. The income differences are similar. Similarly, individuals without a college degree have, on average, poorer health than those with a college degree. 
Table 1: Descriptive statistics

\begin{tabular}{|c|c|c|c|}
\hline & Mean & S.D. & Observations \\
\hline \multicolumn{4}{|l|}{ Entire sample } \\
\hline Age & 68.49 & 10.46 & 133,079 \\
\hline Frailty & 0.21 & 0.15 & 133,079 \\
\hline Total household net worth (2014 $000 \$$ ) & 567.91 & $1,667.38$ & 133,079 \\
\hline Total household income (2014000\$) & 76.06 & 183.41 & 133,079 \\
\hline \multicolumn{4}{|l|}{ College education } \\
\hline Age & 66.64 & 10.18 & 29,240 \\
\hline Frailty & 0.15 & 0.12 & 29,240 \\
\hline Total household net worth & $1,133.83$ & $2,921.83$ & 29,240 \\
\hline Total household income & 138.15 & 303.26 & 29,240 \\
\hline \multicolumn{4}{|l|}{ No college education } \\
\hline Age & 69.01 & 10.47 & 103,820 \\
\hline Frailty & 0.22 & 0.15 & 103,820 \\
\hline Total household net worth & 408.61 & $1,021.64$ & 103,820 \\
\hline Total household income & 58.58 & 125.80 & 103,820 \\
\hline \multicolumn{4}{|l|}{ Age $<70$} \\
\hline Age & 60.69 & 5.26 & 74,062 \\
\hline Frailty & 0.17 & 0.13 & 74,062 \\
\hline Total household net worth & 571.97 & $1,906.53$ & 74,062 \\
\hline Total household income & 94.37 & 227.52 & 74,062 \\
\hline \multicolumn{4}{|l|}{ Age $\geq 70$} \\
\hline Age & 78.28 & 6.31 & 59,017 \\
\hline Frailty & 0.25 & 0.16 & 59,017 \\
\hline Total household net worth & 562.82 & $1,306.76$ & 59,017 \\
\hline Total household income & 53.09 & 99.70 & 59,017 \\
\hline \multicolumn{4}{|c|}{ Top 20 percent of the frailty distribution } \\
\hline Age & 68.70 & 10.31 & 24,963 \\
\hline Frailty & 0.44 & 0.14 & 24,963 \\
\hline Total household net worth & 269.59 & 786.50 & 24,963 \\
\hline Total household income & 44.60 & 78.26 & 24,963 \\
\hline \multicolumn{4}{|c|}{ Bottom 80 percent of the frailty distribution } \\
\hline Age & 68.44 & 10.49 & 108,116 \\
\hline Frailty & 0.15 & 0.09 & 108,116 \\
\hline Total household net worth & 636.79 & 1.803 .88 & 108,116 \\
\hline Total household income & 83.33 & 199.27 & 108,116 \\
\hline
\end{tabular}




\section{Empirical approach}

The paper aims to understand the impact of health on wealth. Although there is evidence that the direction of the impact from health to wealth is more significant than the impact from wealth to health, education and parental status appear to be important for health outcomes (Smith (2004)). As Table 1 shows, the household net worth of college-educated and healthier individuals is higher than that of unhealthy. This implies that the endogeneity between wealth and health cannot be ruled out. In this paper, I aim to assess whether the impact of health on wealth is significant, accounting for the dynamic relationship between them The empirical approach closely follows Hosseini, Kopecky, and Zhao (2019b) except that I want to analyze the impact of health on wealth and not on earnings. Specifically, I run the following model.

$$
w_{i, t}=a_{i}+\lambda_{t}+\beta h_{i, t}+\sum_{j=1}^{4} \alpha_{j} w_{i, t-j}+\gamma \mathbf{X}_{i, t}+\epsilon_{i, t} .
$$

In equation (1), $w_{i, t}$ is the log of individual $\left(i^{\prime} s\right)$ wealth (household wealth) at time $t$. On the right-hand side, $a_{i}$ is the time-invariant individual fixed effect, which controls for the potential unobserved individual-specific heterogeneity. For example, it could include genetic endowment that affects both health as well as wealth or any potentially omitted variable. The time dummy, $\lambda_{t}$, is essential to account for the year-specific effects on wealth, although they may or may not affect an individual's health. For example, the average effect of the great recession on individual wealth in 2008 is accounted for by $\lambda_{2008}$. Health status is represented by $h_{i, t}$, which shows individual $i$ 's frailty at time $t$. Larger the $h_{i, t}$, the poorer the health (the more frail the individual). $\mathbf{X}_{i, t}$ is a set of control variables including $\log$ total household income, individual's education, marital status, family size, number of alive siblings, father's education, long term care insurance, and a cubic polynomial on age. Family size and number of siblings are included in the model to account for the potential impact of 
family size on wealth or the impact of wealth on family size. In the regressions, I assume that the past shocks to wealth might have an effect on family size or the number of alive siblings. The number of siblings may also have an impact on inheritance, which is an important constituent of wealth. Further, I include the father's education to control for the impact of parental income (or socio-economic status during childhood) on health and wealth later in life. The inclusion of the dummy for the long term care insurance is motivated by the finding in Lockwood (2018) that the possession of long term care (LTC) insurance increases with wealth. One could argue that having LTC coverage could minimize potential wealth loss due to a bad health shock. This leads us to treat the LTC status as an endogenous variable. Another endogenous variable in the model is the total household income. The reason behind treating it as endogenous is that it includes labor as well as capital income. The inclusion of capital income means that current shocks to wealth could affect current income. For instance, a stock market crash that reduces the value of wealth held in stocks could also mean lower dividend income, which is part of household capital income. Likewise, owning a number of houses could increase the rent income, leading to higher total household income. In equation $1, \epsilon_{i, t}$ is the random error term. I assume that

$$
E\left(a_{i}\right)=E\left(\epsilon_{i t}\right)=E\left(a_{i} \epsilon_{i t}\right)=0 .
$$

To estimate the coefficients, I use the dynamic panel data approach adopted by many papers in economics and finance. One such paper I follow is Wintoki, Linck, and Netter (2012). These methods were introduced by Holtz-Eakin, Newey, and Rosen (1988) and further developed and popularized by the works of Arellano and Bond (1991), Arellano and Bover (1995), and Blundell and Bond (1998). As outlined in Roodman (2009), these estimators are relevant for my purpose for the following reasons: (1) HRS (2000-2014) is a small $T$, large $N$ data (only eight waves but a large number of individuals), (2) wealth (dependent variable) depends on its own past, (3) regressors such as health, or lagged value of wealth could be correlated with the past errors, (4) presence of unobserved (but presumably time- 
invariant) individual heterogeneity $\left(a_{i}\right),(5)$ heteroskedasticity and auto-correlation within the individuals over time but not across the individuals, and (6) linear functional relationship (by assumption). The estimation procedure proceeds in two steps. In the first step, I create the following first-differenced equation by eliminating the time-invariant individual-specific effects, $a_{i}$.

$$
\Delta w_{i, t}=\beta \Delta h_{i, t-1}+\sum_{j=1}^{4} \alpha_{j} \Delta w_{i, t-j}+\gamma \Delta \mathbf{X}_{i, t}+\Delta \epsilon_{i, t}
$$

$\beta$ thus estimated using Equation (2) is called the "difference GMM estimator". The next step is to use the lagged values of wealth, health, and other control variables as their instruments to estimate the coefficients. For instrument validity, the following moment conditions must hold.

$$
E\left(w_{i, t-s} \Delta \epsilon_{i, t}\right)=E\left(h_{i, t-s} \Delta \epsilon_{i, t}\right)=0, \quad \text { for } s>4
$$

While the first differencing removes the time-invariant individual-specific unobserved heterogeneity, the difference GMM estimator uses the lagged levels as the instruments for the first differenced variables. Arellano and Bover (1995) and Blundell and Bond (1998) point out that lagged levels are often poor instruments for the fist differenced variables, especially when the variables in question are highly persistent. In that case, the difference GMM estimator is likely to be inefficient because first differencing persistent variables such as wealth and health is likely to remove most of the variation. Blundell and Bond (1998) propose "system GMM estimator" to increase the efficiency of the difference GMM estimator. They suggest including the level equations in addition to the first differenced equations (equation (22) so that the estimators contain more "information". Specifically, system GMM doubles the observations by creating a $\Delta w_{i, t}$ for every $w_{i, t}$ and stacking them as follows.

$$
\left[\begin{array}{c}
\Delta w_{i, t} \\
w_{i, t}
\end{array}\right]=\eta+\beta\left[\begin{array}{c}
\Delta f_{i, t-1} \\
f_{i, t-1}
\end{array}\right]+\alpha_{j} \sum_{j=1}^{4}\left[\begin{array}{c}
\Delta w_{i, t-j} \\
w_{i, t-j}
\end{array}\right]+\gamma\left[\begin{array}{c}
\Delta \mathbf{X}_{i, t} \\
\mathbf{X}_{i, t}
\end{array}\right]+\epsilon_{i, t}
$$


Notice, however, that $\epsilon_{i t}$ in equation (4) includes the unobserved heterogeneity $a_{i}$ present in equation (1). If $a_{i}$ is correlated with the regressors, and this correlation varies over time, it will lead to inconsistent estimates. Note that I am not including fixed effects in the level equation. First-differencing removes them out of the fixed effect equation. Therefore, $\bar{e}_{i}$ never appears in the error term. Now I only need to address the bias caused by $a_{i}$ remaining in the error term. To overcome this problem, I assume that such a correlation is constant over time. It is a reasonable assumption, especially in a small $T$ panel data as the one this paper uses. Consider, for instance, the impact of genetic endowment on health. While certain individuals may be healthier than others due to the genes they inherit from their parents, it is unlikely that the effect of genes on health will change in a few years. This assumption requires us to make the following additional moment conditions.

$$
E\left[\Delta w_{i, t-s}\left(a_{i}+\epsilon_{i, t}\right)\right]=E\left[\Delta f_{i, t-s}\left(a_{i}+\epsilon_{i, t}\right)\right]=0, \quad \text { for } s>4
$$

The moment conditions in (5), ensure that the unobserved heterogeneity present in the level equations do not correlate the past or current error terms to the differences $\left(\Delta w_{i, t-s}\right.$, $\Delta f_{i, t-s}$, and $\left.\Delta \mathbf{X}_{i, t}\right)$ when I use levels as instruments in the equations in differences. In addition, if the above exogeneity assumptions are correct, then the following conditions must hold.

$$
E\left[X_{i t-s} \epsilon_{i t}\right]=E\left[w_{i t-s} \epsilon_{i t}\right]=0, \quad \text { for } s>4
$$

While the current shocks to wealth could be correlated to health, one cannot rule out the possibility of dynamic endogeneity. That is, it is likely that past health affects current wealth and past wealth also affects current health as well as current wealth. It is clear that dynamic endogeneity further complicates a clear identification of the impact of health on wealth. As a solution to this problem, I include the first four lags of wealth as regressors. How do I determine how many lags to use? I follow the approach adopted by Wintoki, Linck, and Netter (2012) as their question has similar complications as the question my 
paper is attempting to address. Although they want to understand how the corporate board structure affects corporate performance, the relation between their dependent and independent variable is full of potential endogeneity concerns. In that sense, this paper has similar concerns. My strategy, as in Wintoki, Linck, and Netter (2012), is to experiment with different lags of $w_{i t}$ and choose the shortest lag that addresses the endogeneity problem. I could use the deepest possible lag to overcome endogeneity, but that increases the risk of suffering the weak IV problem. Choosing an appropriate number of lags involves adequately addressing both concerns.

To determine whether I have addressed endogeneity concerns, I use several tests suggested by Arellano and Bond (1991). A key assumption in my setup is that the current shocks to wealth are independent of the past wealth and the individual-specific characteristics beyond certain lags. This follows from the earlier discussion of why I carefully choose the number of lags of wealth to use as regressors. To test the validity of this assumption, Arellano and Bond (1991) suggest two tests. The first is the test of the second-order serial correlation, $A R(2)$ test. The idea is that if I have included enough lags of wealth as regressors, then its past values (as well as the past values of other endogenous variables) beyond this lag must be exogenous to the current shocks to wealth. In other words, if I use the first $k$ lags of wealth as regressors, then the $k+1$ and deeper lags of wealth and other endogenous variables are their valid IVs. Based on the empirical specification, the residuals in the first difference will be correlated. That is, the null hypothesis that $A R(1)$ is zero will likely be rejected. To see why note that in the first-differenced model

$$
\Delta w_{i, t}=\eta+\beta \Delta h_{i, t}+\sum_{j=1}^{4} \alpha_{j} \Delta w_{i, t-j}+\gamma \Delta \mathbf{X}_{i, t}+\Delta \epsilon_{i, t}
$$

where $\Delta \epsilon_{i, t}=\epsilon_{i, t}-\epsilon_{i, t-1}$. At $t-1, \Delta \epsilon_{i, t-1}=\epsilon_{i, t-1}-\epsilon_{i, t-2}$. Since $\epsilon_{i, t-1}$ is present in $\Delta \epsilon_{i, t}$ and $\Delta \epsilon_{i, t-1}$, the first-differenced residuals will most likely be serially correlated. If the model specification is correct, the residuals should not exhibit significant second order serial 
correlation, $A R(2)$. In the context of the model, this means that I should be unable to reject the null hypothesis that $A R(2)$ is zero. Arellano and Bond (1991) suggest a second test, called the Hansen test of over-identification. Its purpose is to test the joint validity of the set of instruments. Since the model uses many lags of control variables as their instruments, the system is over-identified. This means that the Hansen-test (Hansen J) can be used to test the null hypothesis that the instruments used in the model are jointly valid. If the instruments used in the model are valid, then I should be unable to reject the null hypothesis. In addition to these two tests, I also report the Difference-in-Hansen test to test the null that instruments used for the level equations are exogenous. Although passing all these tests cannot completely eliminate potential bias in the estimates (Wintoki, Linck, and Netter (2012)), the Hansen J test becomes more reliable as the sample size increases. A likely reason for the weak Hansen $\mathrm{J}$ test is instrument proliferation with the number of lags used. In the main models, the number of instruments remains around 40 with 32,880

observations. Note, however, that all the tests I described assume that the model is correctly specified.

\subsection{How many lags of wealth to include as regressors?}

To decide on how many lags of wealth variable are to be included as regressors, I run the OLS of $\log$ wealth on the same control variables with different lags of wealth as regressors, similar to the approach adopted by Wintoki, Linck, and Netter (2012). Including enough lags is essential for the dynamic completeness of the model (Wintoki, Linck, and Netter (2012)). 
Table 2: How many lags of wealth to include as regressors?

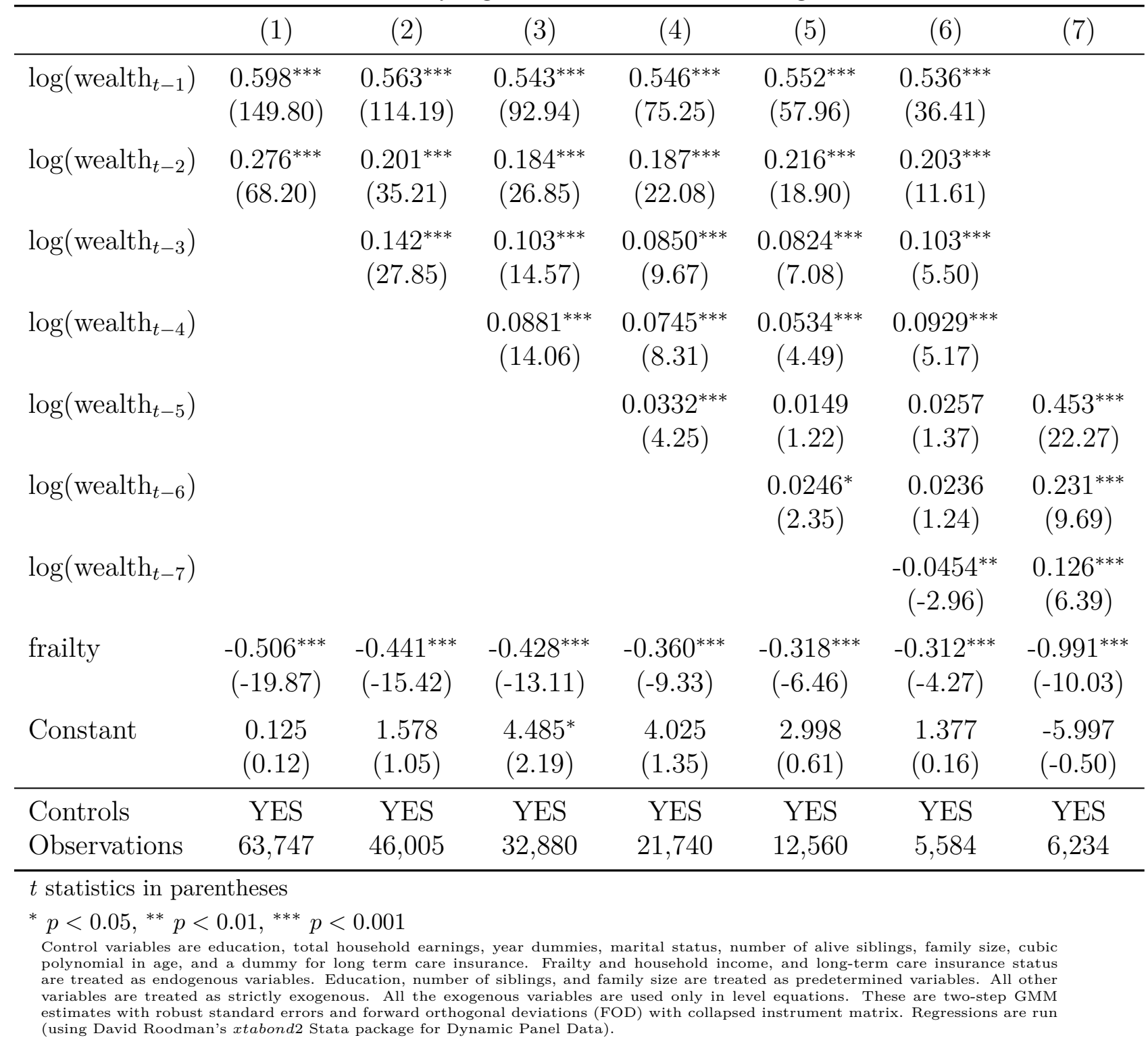

It appears from the results in Table 2 that the first four lags are always significant for predicting current wealth level. Columns (5) and (6) show that as I include deeper lags, the significance of the lags after the fourth lag decreases. In column (5), the coefficient on the fifth lag becomes while the coefficient on the sixth lag is still significant. To understand whether the sixth lag is really important, I run the OLS with up to the seventh lags of wealth as regressors. With the seventh lags included, coefficients of both the fifth and the sixth lags become insignificant. The coefficients of later lags are smaller, indicating that deeper lags 
are a relatively weaker predictor of current wealth. Notice that while the coefficient on the seventh lag is significant, it turns negative. Since I can only use up to seven lags, I decide that the first four lags are sufficient to account for the impact of past wealth on current wealth, health, and other endogenous variables. If later lags were more informative about the prior lags, one should be able to observe the increased power of later lags if the first few lags were excluded as regressors and only later lags were included. This is precisely what is observed in column (7), where I report the result of excluding the first four lags but including only the fifth to the seventh lags of wealth as regressors. This behavior of the coefficients of the lag tells us that the first four lags of wealth should be enough to account for the effect of past wealth on frailty and other individual-specific characteristics.

\subsection{Importance of dynamic relation between frailty and wealth}

To highlight the importance of accounting for the dynamic relationship between frailty and past wealth, I run the following model ${ }^{6}$

- An OLS model, in which I ignore the dynamic relationship between wealth and frailty and the individual-specific unobserved heterogeneity. I call it the Static OLS model.

- A static fixed-effects model, in which I ignore the dynamic relationship between wealth and frailty but account for individual-specific unobserved heterogeneity.

- A dynamic OLS model, which takes into account the dyanmic relationship between wealth and health but ignores the individual-specific unobserved heterogeneity. I call it the Static FE model.

- A dynamic fixed-effects model (system GMM), in which I account for the dynamic relationship between the dependent and independent variables and the time-invariant individual-specific unobserved heterogeneity.

6. Here, I follow the approach adopted by Wintoki, Linck, and Netter $(2012)$ to show the importance of dynamic relation between corporate performance and board structure. 
The results are presented in Table 3. The effect of frailty on wealth is negative and significant in all the models. Notice, however, that the magnitude of the coefficient and the t-statistic (all based on robust, individual-clustered standard errors) are quite different across the specifications. In the static OLS model, I have accounted for the potential correlation of individual-specific errors over time by using cluster-robust errors. But there are two crucial shortcomings of this model. First, the static nature of the model means that it ignores the dynamic relation between wealth, frailty, and other explanatory variables. Table 2 has already shown that there is a significant dynamic relationship between health and wealth. The importance of dynamic relation is evident from the drastic decline in the magnitude of the frailty coefficient in the second column of Table 3 in the dynamic OLS model. Another evidence is observed in a sharp improvement in $R^{2}$ from the static OLS to the dynamic OLS model. This could also imply that current frailty is correlated with past wealth. Second, OLS ignores the individual-specific unobserved heterogeneity, which could be important for explaining the impact of frailty on wealth. The past wealth level may not fully capture such heterogeneity. To address these concerns, I account for the dynamic nature of the relationship as well as the potential role of unobserved heterogeneity by using system GMM to estimate the coefficients (column (4)). Observe that the coefficient declines sharply from static FE model to system GMM. This is because the static FE estimator is likely to be positively biased if frailty is negatively correlated to past wealth (since I ignore the dynamic nature of the relationship in the static FE model). The sharp decline in coefficient from the static OLS model to the dynamic OLS model shows that there is a negative correlation between frailty and past wealth. 
Table 3: How important is the dynamic relation between frailty and wealth?

\begin{tabular}{|c|c|c|c|c|}
\hline & Static OLS & Dynamic OLS & Static FE & System GMM \\
\hline frailty & $\begin{array}{c}-2.301^{* * *} \\
(-33.46)\end{array}$ & $\begin{array}{c}-0.466^{* * *} \\
(-10.40)\end{array}$ & $\begin{array}{c}-0.704^{* * *} \\
(-11.26)\end{array}$ & $\begin{array}{c}-2.143^{* * *} \\
(-3.57)\end{array}$ \\
\hline $\log \left(\right.$ wealth $\left._{t-1}\right)$ & & $\begin{array}{c}0.546^{* * *} \\
(49.95)\end{array}$ & & $\begin{array}{l}0.248 \\
(1.03)\end{array}$ \\
\hline $\log \left(\right.$ wealth $\left._{t-2}\right)$ & & $\begin{array}{c}0.187^{* * *} \\
(16.47)\end{array}$ & & $\begin{array}{l}0.463^{*} \\
(2.05)\end{array}$ \\
\hline $\log \left(\right.$ wealth $\left._{t-3}\right)$ & & $\begin{array}{c}0.0948^{* * *} \\
\quad(8.97)\end{array}$ & & $\begin{array}{l}-0.134 \\
(-0.65)\end{array}$ \\
\hline $\log \left(\right.$ wealth $\left._{t-4}\right)$ & & $\begin{array}{c}0.0878^{* * *} \\
(9.73)\end{array}$ & & $\begin{array}{l}0.317 \\
(1.88)\end{array}$ \\
\hline$R^{2}$ & 0.35 & 0.77 & 0.18 & \\
\hline AR $(1)$ test ( $p$-value) & & & & 0.024 \\
\hline $\operatorname{AR}(2)$ test (p-value) & & & & 0.223 \\
\hline Hansen test of over-identification (p-value) & & & & 0.562 \\
\hline Diff-in-Hansen test of exogeneity (p-value) & & & & 0.562 \\
\hline Constant & $\begin{array}{l}1.605 \\
(1.01)\end{array}$ & $\begin{array}{l}3.514 \\
(1.41)\end{array}$ & $\begin{array}{c}9.094^{* * *} \\
(7.27)\end{array}$ & $\begin{array}{l}11.57 \\
(1.74)\end{array}$ \\
\hline Controls & Yes & Yes & Yes & Yes \\
\hline Observations & 111,667 & 35,623 & 111,667 & 32,880 \\
\hline
\end{tabular}

$t$ statistics in parentheses

${ }^{*} p<0.05,{ }^{* *} p<0.01,{ }^{* * *} p<0.001$

Control variables are education, total household earnings, year dummies, marital status, number of alive siblings, family size, cubic polynomial in age, and a dummy for long term care insurance. Frailty and household income, and long-term care insurance status are treated as endogenous variables. Education, number of siblings, and family size are treated as predetermined variables. All other variables are treated as strictly exogenous. All the exogenous variables are used only in level equations. These are two-step GMM estimates with robust standard errors and forward orthogonal deviations (FOD) with collapsed instrument matrix. Regressions are run (using David Roodman's xtabond2 Stata package for Dynamic Panel Data).

I also report the result of the test for serial correlation on residual errors for the level equations. The $\mathrm{AR}(2)$ value is 0.223 , implying that I cannot reject the null hypothesis of no second order serial correlation. I also test for overidentifying restrictions. The J-test has p-value of 0.562 , implying that I cannot reject the null hypothesis that the instruments are valid. Finally, the Diff-in-Hansen test for exogeneity (under the null that the instruments used for the level equations are exogenous) with p-value of 0.562 shows that I cannot reject the null hypothesis that the subset of instruments used in the level equations are exogenous (Eichenbaum, Hansen, and Singleton (1988)). 


\section{Results}

Table 4 presents the main results. Recall that this paper is interested in the effect of frailty on wealth. The results show that frailty has a significantly negative impact on wealth. Recall that I used 36 different health deficits in the construction of the frailty index. The coefficient of frailty in column 1 of Table 4 shows that an additional deficit reduces household net worth by $\frac{(\exp (\beta)-1)}{36}=2.45$ percentage points on average. The model passes all the tests essential to address potential endogeneity and IV validity issues. As explained earlier, the null of no first order serial correlation in the residual differences is rejected at 95 percent confidence level. This is to be expected due to the way first-differencing works. But the results must pass the $\operatorname{AR}(2)$ test, which they do as the null hypothesis of no second order serial correlation on residual differences cannot be rejected. The results also pass the Hansen test of overidentification, meaning I cannot reject the null hypothesis that the set of instruments used in the equations in levels are jointly valid. I further run the difference-in-Hansen test of exogeneity of the instruments used for endogenous variables. Since I cannot reject the null hypothesis that the set of instruments are exogenous, it must be the case that the instruments are not endogenous. For all the results presented in Table4 4 use the 6-7 lags of endogenous variables and wealth as instruments. I experiment with different combinations of lags (see Table 11, 12, 13, 14, and 15 in Appendix B). I find that using fifth lag results into the rejection of the null of exogeneity of instruments. As suggested by Roodman (2009), I use sixth lag as the beginning lag. With lags 6-7, results pass all the three tests, which are reported.

Recall that household income, frailty, and long term care insurance status are the endogenous variables along with the wealth. Education, number of siblings and family size are treated as predetermined variables as past shock to wealth could affect the current realizations of these variables. Finally, the year dummies, cubic polynomial in age, and marital status are treated as strictly exogenous variables and used only for the level equations. I col- 
lapse the instruments to prevent quadratic increase in number of instruments with number of time periods.

\subsection{Potential mechanisms}

Given that the impact of frailty on wealth is significant and negative, I next want to disentangle the effect into different channels. To that end, estimate the effect of frailty among different groups. First, I consider individuals younger than 70 and individuals 70 or older. In Table 4, I label them as "young" and "old", respectively. Column 2 shows that it is the elderly who face the severe wealth loss due to bad health. This is not surprising because frailty increases with age while the earning potential declines. In fact, the impact is insignificant among the people younger than 70 . Observe that the results pass all the tests required to ensure validity of the results.

The second potential mechanism I consider is education. To evaluate the effect of frailty on wealth by education, I run the model with frailty interacted with the dummy for college education or no college education. The results show that the effect of frailty on wealth is significant and negative among the individuals with no college education and insignificant and negative among the college educated. These results are intuitive because, as Table 1 shows, average frailty among the individuals without college degree is 0.22 , while it is 0.15 among the college educated. Average household net worth among the college educated is close to thrice as much as among the people without college degree. College educated have lower average frailty at any age from 50 through 100 (Figure 2). Column 3 of Table 4 shows that the impact among people without college degree is nearly twice as much as among those with college degree. As the tests show, the instruments used in the analysis are jointly exogenous.

The third mechanism I consider is the impact across the frailty distribution. 
Table 4: Effect of frailty on wealth

\begin{tabular}{|c|c|c|c|c|c|}
\hline & (1) & (2) & $(3)$ & $(4)$ & $(5)$ \\
\hline $\log \left(\right.$ wealth $\left._{t-1}\right)$ & $\begin{array}{l}0.248 \\
(1.02)\end{array}$ & $\begin{array}{c}0.625^{* *} \\
(2.79)\end{array}$ & $\begin{array}{l}0.380 \\
(1.66)\end{array}$ & $\begin{array}{l}0.242 \\
(1.07)\end{array}$ & $\begin{array}{l}0.317 \\
(1.08)\end{array}$ \\
\hline $\log \left(\right.$ wealth $\left._{t-2}\right)$ & $\begin{array}{l}0.463^{*} \\
(2.05)\end{array}$ & $\begin{array}{l}0.294 \\
(1.25)\end{array}$ & $\begin{array}{l}0.463^{*} \\
(2.03)\end{array}$ & $\begin{array}{l}0.485^{*} \\
(2.27)\end{array}$ & $\begin{array}{l}0.468 \\
(1.83)\end{array}$ \\
\hline $\log \left(\right.$ wealth $\left._{t-3}\right)$ & $\begin{array}{l}-0.134 \\
(-0.65)\end{array}$ & $\begin{array}{l}-0.325 \\
(-1.62)\end{array}$ & $\begin{array}{l}-0.222 \\
(-1.11)\end{array}$ & $\begin{array}{l}-0.109 \\
(-0.55)\end{array}$ & $\begin{array}{l}-0.162 \\
(-0.69)\end{array}$ \\
\hline $\log \left(\right.$ wealth $\left._{t-4}\right)$ & $\begin{array}{l}0.317 \\
(1.88)\end{array}$ & $\begin{array}{l}0.278 \\
(1.64)\end{array}$ & $\begin{array}{l}0.253 \\
(1.65)\end{array}$ & $\begin{array}{l}0.297 \\
(1.82)\end{array}$ & $\begin{array}{l}0.279 \\
(1.69)\end{array}$ \\
\hline frailty & $\begin{array}{c}-2.143^{* * *} \\
(-3.57)\end{array}$ & & & & \\
\hline frailty $\times$ old & & $\begin{array}{c}-1.672^{* *} \\
(-3.18)\end{array}$ & & & \\
\hline frailty $\times$ young & & $\begin{array}{l}-0.515 \\
(-0.62)\end{array}$ & & & \\
\hline frailty $\times$ college & & & $\begin{array}{l}-0.881 \\
(-1.60)\end{array}$ & & \\
\hline frailty $\times$ no college & & & $\begin{array}{c}-1.603^{* * *} \\
(-3.98)\end{array}$ & & \\
\hline frailty $\times$ good health & & & & $\begin{array}{l}-2.761 \\
(-1.18)\end{array}$ & \\
\hline frailty $\times$ bad health & & & & $\begin{array}{c}-2.055^{* *} \\
(-2.68)\end{array}$ & \\
\hline frailty $\times$ retired & & & & & $\begin{array}{c}-2.159^{* *} \\
(-3.06)\end{array}$ \\
\hline frailty $\times$ not retired & & & & & $\begin{array}{l}-1.678 \\
(-0.97)\end{array}$ \\
\hline $\mathrm{AR}(1)$ test ( $\mathrm{p}$-value) & 0.025 & 0.007 & 0.027 & 0.019 & 0.044 \\
\hline $\operatorname{AR}(2)$ test (p-value) & 0.223 & 0.347 & 0.208 & 0.182 & 0.263 \\
\hline Hansen test of over-identification (p-value) & 0.563 & 0.362 & 0.254 & 0.438 & 0.681 \\
\hline Diff-in-Hansen test of exogeneity (p-value) & 0.476 & 0.159 & 0.145 & 0.432 & 0.522 \\
\hline Constant & $\begin{array}{l}11.56 \\
(1.74)\end{array}$ & $\begin{array}{l}10.69 \\
(1.73)\end{array}$ & $\begin{array}{l}3.211 \\
(0.99)\end{array}$ & $\begin{array}{l}9.226 \\
(1.52)\end{array}$ & $\begin{array}{l}13.50 \\
(1.74)\end{array}$ \\
\hline Controls & Yes & Yes & Yes & Yes & Yes \\
\hline Observations & 32,880 & 32,880 & 32,880 & 32,880 & 32,880 \\
\hline
\end{tabular}

$t$ statistics in parentheses

${ }^{*} p<0.05,{ }^{* *} p<0.01,{ }^{* * *} p<0.001$

Control variables are education, total household earnings, year dummies, marital status, number of alive siblings, family size, cubic polynomial in age, and a dummy for long term care insurance. Frailty and household income, and long-term care insurance status are treated as endogenous variables. Education, number of siblings, and family size are treated as predetermped variables. All other variables are treated as strictly exogenous. All the exogenous variables are used only in level equations. These are two-step TMM estimates with robust standard errors and forward orthogonal deviations (FOD) with collapsed instrument matrix. Regressions are run (using David Roodman's xtabond2 Stata package for Dynamic Panel Data). Individuals older than 70 years of age are treated as "old". Those younger than 70 are treated as "young". "college" is 1 if the individual has college degree or above. Individuals without college degree are classified as "no college". Individuals in the fifth quintile of the frailty distribution are treated to be in 
For simplicity, I consider two groups: those with "good" health and those with "bad" health. I define those in the top frailty quintile as having bad health and everyone else having good health. Column 4 of Table 4 shows that the impact is significant among the ones with bad health. Although the coefficient for good health interacted with frailty is bigger, it is insignificant. The results illustrate that irrespective of age or education, bad health leads to wealth loss. The hypothesis that health affects wealth is further strengthened by this evidence.

I also consider a fourth mechanism-retirement. It has been argued that health could affect retirees and non-retirees differently. The reason is that the retirees' can not earn regular wage to weather the health shocks while non-retirees potentially can. The results appear consistent with this hypothesis. Although I do not analyze why there is larger effect of health on wealth among the retirees and not among the non-retirees, the results provide evidence that retirees face significant wealth loss due to poor health. Note that the results are also consistent with Hosseini, Kopecky, and Zhao (2019b), who find that individuals poorer education suffer larger earnings losses due to bad health.

\subsection{Consistency of the estimates}

Recall that the estimates rely on exploiting the dynamic relation between frailty and wealth available in dynamic panel data. An important feature of the specification is that it contains lagged values of dependent variable (wealth) as regressors. From equation (1), $\alpha_{1}$, $\alpha_{2}, \alpha_{3}$, and $\alpha_{4}$ are the coefficients on the lags of wealth. The OLS estimates of these coefficients are positively biased while the fixed-effects estimates of the coefficients are negatively biased (Nickell (1981), Arellano and Bond (1991), Bond (2002b)), leading to inconsistent estimators. 
Table 5: Comparison of static OLS, FE, and System GMM

\begin{tabular}{lccc}
\hline & OLS & FE & System GMM \\
\hline $\log \left(\right.$ wealth $\left._{t-1}\right)$ & $0.546^{* * *}$ & $-0.0825^{* * *}$ & 0.248 \\
& $(49.95)$ & $(-5.47)$ & $(1.02)$ \\
$\log \left(\right.$ wealth $\left._{t-2}\right)$ & $0.187^{* * *}$ & $-0.104^{* * *}$ & $0.463^{*}$ \\
& $(16.47)$ & $(-8.44)$ & $(2.05)$ \\
$\log \left(\right.$ wealth $\left._{t-3}\right)$ & $0.0948^{* * *}$ & $-0.0692^{* * *}$ & -0.134 \\
& $(8.97)$ & $(-6.08)$ & $(-0.65)$ \\
$\log \left(\right.$ wealth $\left._{t-4}\right)$ & $0.0878^{* * *}$ & $-0.0300^{* *}$ & 0.317 \\
& $(9.73)$ & $(-2.75)$ & $(1.88)$ \\
frailty & $-0.466^{* * *}$ & $-0.468^{* * *}$ & $-2.143^{* * *}$ \\
& $(-10.40)$ & $(-4.81)$ & $(-3.57)$ \\
AR(1) test $(p-v a l u e)$ & & & 0.025 \\
AR(2) test $(p-v a l u e)$ & & & 0.223 \\
Hansen test of over-identification (p-value) & & & 0.563 \\
Diff-in-Hansen test of exogeneity (p-value) & & & 0.476 \\
Constant & 3.467 & $17.76^{* * *}$ & 11.56 \\
& $(1.39)$ & $(3.54)$ & $(1.74)$ \\
\hline Controls & Yes & Yes & Yes \\
Observations & 35,623 & 35,623 & 32,880 \\
\hline
\end{tabular}

$t$ statistics in parentheses

${ }^{*} p<0.05,{ }^{* *} p<0.01,{ }^{* * *} p<0.001$

Control variables are education, total household earnings, year dummies, marital status, number of alive siblings, family size, cubic polynomial in age, and a dummy for long term care insurance. Frailty and household income, and long-term care insurance status are treated as endogenous variables. Education, number of siblings, and family size are treated as predetermined variables. All other variables are treated as strictly exogenous. All the exogenous variables are used only in level equations. These are two-step GMM estimates with robust standard errors and forward orthogonal deviations (FOD) with collapsed instrument matrix. Regressions are run (using David Roodman's xtabond2 Stata package for Dynamic Panel Data).

System GMM helps improve on reducing bias and thus consistently estimating the coefficients $\alpha_{1}, \alpha_{2}, \alpha_{3}$, and $\alpha_{4}$. In context of the model, this means that the sum of the coefficients on $\log \left(\right.$ wealth $\left._{t-1}\right), \log \left(\right.$ wealth $\left._{t-2}\right), \log \left(\right.$ wealth $\left._{t-3}\right)$, and $\log \left(\right.$ wealth $\left._{t-4}\right)$ using system GMM must lie between such sums while using OLS and FE estimators. The results of the regressions are presented in Table 5. The results pass this test, implying that the system GMM estimates are consistent. 


\subsection{Test for reverse causality}

It is possible that the direction of causality is from wealth to health. That is, not having enough wealth leads to poor health. To test this hypothesis, I run the following model using system GMM.

$$
h_{i, t}=a_{i}+\lambda_{t}+\beta w_{i, t}+\sum_{j=1}^{4} \alpha_{j} h_{i, t-j}+\gamma \mathbf{X}_{i, t}+\epsilon_{i, t}
$$

Equation (8) is different from equation (1) in that unlike in equation (1), the dependent variable in equation (8) is health. Here I want to see whether the results above are driven by the impact of wealth on frailty rather than what I have argued in this paper. Before running the model, I first check how many lags of frailty are important to account for the impact of past health on current health and wealth. It appears that three lags of frailty are sufficient. Table 6 shows that the results are not driven by reverse causality. 
Table 6: The effect of wealth on frailty

\begin{tabular}{|c|c|c|c|c|c|}
\hline & (1) & $(2)$ & (3) & $(4)$ & $(5)$ \\
\hline $\log \left(\right.$ frailty $\left._{t-1}\right)$ & $\begin{array}{c}1.120^{* * *} \\
(3.54)\end{array}$ & $\begin{array}{c}0.951^{* * *} \\
(3.63)\end{array}$ & $\begin{array}{c}0.845^{* * *} \\
(3.93)\end{array}$ & $\begin{array}{c}1.161^{* * *} \\
(4.14)\end{array}$ & $\begin{array}{c}1.019^{* * *} \\
(3.57)\end{array}$ \\
\hline $\log \left(\right.$ frailty $t-2_{t-2}$ & $\begin{array}{l}0.546 \\
(1.23)\end{array}$ & $\begin{array}{c}0.811^{*} \\
(2.04)\end{array}$ & $\begin{array}{c}-0.0392 \\
(-0.11)\end{array}$ & $\begin{array}{l}0.738 \\
(1.86)\end{array}$ & $\begin{array}{l}0.738 \\
(1.80)\end{array}$ \\
\hline $\log \left(\right.$ frailty $\left._{t-3}\right)$ & $\begin{array}{c}0.0659 \\
(0.16)\end{array}$ & $\begin{array}{c}-0.0498 \\
(-0.15)\end{array}$ & $\begin{array}{l}-0.301 \\
(-1.04)\end{array}$ & $\begin{array}{l}-0.115 \\
(-0.30)\end{array}$ & $\begin{array}{c}0.0807 \\
(0.21)\end{array}$ \\
\hline $\log \left(\right.$ frailty $\left._{t-4}\right)$ & $\begin{array}{l}-0.354 \\
(-1.18)\end{array}$ & $\begin{array}{l}-0.333 \\
(-1.29)\end{array}$ & $\begin{array}{l}-0.144 \\
(-0.64)\end{array}$ & $\begin{array}{l}-0.422 \\
(-1.68)\end{array}$ & $\begin{array}{l}-0.515 \\
(-1.95)\end{array}$ \\
\hline wealth $_{t}$ & $\begin{array}{r}-0.0187 \\
(-1.39)\end{array}$ & & & & \\
\hline wealth $\times$ old & & $\begin{array}{c}-0.0212 \\
(-1.88)\end{array}$ & & & \\
\hline wealth $\times$ young & & $\begin{array}{c}-0.0185 \\
(-1.69)\end{array}$ & & & \\
\hline wealth $\times$ good health & & & $\begin{array}{c}-0.0148 \\
(-1.62)\end{array}$ & & \\
\hline wealth $\times$ bad health & & & $\begin{array}{c}0.0104 \\
(1.02)\end{array}$ & & \\
\hline wealth $\times$ college & & & & $\begin{array}{c}0.0132 \\
(0.65)\end{array}$ & \\
\hline wealth $\times$ no college & & & & $\begin{array}{c}-0.0159 \\
(-1.52)\end{array}$ & \\
\hline wealth $\times$ retired & & & & & $\begin{array}{c}-0.00615 \\
(-1.21)\end{array}$ \\
\hline wealth $\times$ not retired & & & & & $\begin{array}{c}-0.00890 \\
(-1.70)\end{array}$ \\
\hline Constant & $\begin{array}{l}0.266 \\
(0.42)\end{array}$ & $\begin{array}{l}0.508 \\
(0.82)\end{array}$ & $\begin{array}{l}0.432 \\
(0.88)\end{array}$ & $\begin{array}{l}0.569 \\
(1.13)\end{array}$ & $\begin{array}{l}1.049 \\
(1.45)\end{array}$ \\
\hline Observations & 32,880 & 32,880 & 32,880 & 32,880 & 32,880 \\
\hline
\end{tabular}

$t$ statistics in parentheses

${ }^{*} p<0.05,{ }^{* *} p<0.01,{ }^{* * *} p<0.001$

Control variables are education, total household earnings, year dummies, marital status, number of alive siblings, family size, cubic polynomial in age, and a dummy for long term care insurance. Frailty and household income, and long-term care insurance status are treated as endogenous variables. Education, number of siblings, and family size are treated as predetermined variables. All other variables are treated as strictly exogenous. All the exogenous variables are used only in level equations. These are two-step GMM estimates with robust standard errors and forward orthogonal deviations (FOD) with collapsed instrument matrix. Regressions are run (using David Roodman's xtabond2 Stata package for Dynamic Panel Data). 


\subsection{Alternative definitions of wealth}

To check robustness of the results, I run the model using three alternative definitions of wealth: total non-housing net worth, total financial net worth (excluding housing), and total housing net worth. The results remain significant across the definitions although the level of significance and the magnitude of coefficients change. I present the results in Table 7 , 8 , and 9. While the results pass all the empirical tests reported, nearly all the results remain significant. One exception is the effect of health on financial wealth among individuals with bad health and the retirees. Noticeably, the effect of frailty financial wealth appears to be the largest among the elderly, individuals without a college degree, and those in poor health. On the other hand, the impact of frailty is the smallest on housing wealth across all groups. The model specification remains the same across three alternative definitions of wealth, except when I define wealth as only financial wealth. The only change here is that I use the seventh lag as an instrument for endogenous variables because using the sixth lag leads to rejection

of the null hypothesis of instrument exogeneity. Despite using the seventh lag, there still is a large and significant effect of frailty on wealth. 
Table 7: Alternatice definitions of wealth-non-housing wealth

\begin{tabular}{|c|c|c|c|c|c|}
\hline & $(1)$ & $(2)$ & $(3)$ & $(4)$ & $(5)$ \\
\hline $\log \left(\right.$ wealth $\left._{t-1}\right)$ & $\begin{array}{l}0.400 \\
(1.54)\end{array}$ & $\begin{array}{l}0.684^{*} \\
(2.56)\end{array}$ & $\begin{array}{c}0.740^{* * *} \\
(3.41)\end{array}$ & $\begin{array}{l}0.542^{*} \\
(2.10)\end{array}$ & $\begin{array}{l}0.590^{*} \\
(2.12)\end{array}$ \\
\hline $\log \left(\right.$ wealth $\left._{t-2}\right)$ & $\begin{array}{l}0.282 \\
(1.15)\end{array}$ & $\begin{array}{l}0.234 \\
(0.93)\end{array}$ & $\begin{array}{c}0.0611 \\
(0.26)\end{array}$ & $\begin{array}{l}0.223 \\
(0.90)\end{array}$ & $\begin{array}{l}0.199 \\
(0.76)\end{array}$ \\
\hline $\log \left(\right.$ wealth $\left._{t-3}\right)$ & $\begin{array}{c}-0.0155 \\
(-0.07)\end{array}$ & $\begin{array}{l}-0.198 \\
(-0.84)\end{array}$ & $\begin{array}{c}0.0455 \\
(0.22)\end{array}$ & $\begin{array}{c}0.0495 \\
(0.24)\end{array}$ & $\begin{array}{c}-0.0798 \\
(-0.33)\end{array}$ \\
\hline $\log \left(\right.$ wealth $\left._{t-4}\right)$ & $\begin{array}{l}0.226 \\
(1.36)\end{array}$ & $\begin{array}{l}0.164 \\
(0.91)\end{array}$ & $\begin{array}{c}0.0853 \\
(0.62)\end{array}$ & $\begin{array}{l}0.147 \\
(0.85)\end{array}$ & $\begin{array}{l}0.187 \\
(1.07)\end{array}$ \\
\hline frailty & $\begin{array}{c}-3.405^{* *} \\
(-2.89)\end{array}$ & & & & \\
\hline frailty $\times$ old & & $\begin{array}{c}-2.527^{* *} \\
(-2.66)\end{array}$ & & & \\
\hline frailty $\times$ young & & $\begin{array}{l}0.574 \\
(0.42)\end{array}$ & & & \\
\hline frailty $\times$ college & & & $\begin{array}{l}-0.644 \\
(-0.82)\end{array}$ & & \\
\hline frailty $\times$ no college & & & $\begin{array}{c}-2.067^{* *} \\
(-2.87)\end{array}$ & & \\
\hline frailty $\times$ good health & & & & $\begin{array}{l}-1.886 \\
(-0.62)\end{array}$ & \\
\hline frailty $\times$ bad health & & & & $\begin{array}{c}-2.416^{*} \\
(-1.97)\end{array}$ & \\
\hline frailty $\times$ retired & & & & & $\begin{array}{c}-2.947^{*} \\
(-2.29)\end{array}$ \\
\hline frailty $\times$ not retired & & & & & $\begin{array}{l}-0.965 \\
(-0.34)\end{array}$ \\
\hline AR(1) test (p-value) & 0.049 & 0.015 & 0.009 & 0.039 & 0.024 \\
\hline $\operatorname{AR}(2)$ test (p-value) & 0.642 & 0.565 & 0.705 & 0.880 & 0.774 \\
\hline Hansen test of over-identification ( $\mathrm{p}$-value) & 0.288 & 0.281 & 0.186 & 0.240 & 0.645 \\
\hline Diff-in-Hansen test of exogeneity (p-value) & 0.284 & 0.217 & 0.146 & 0.165 & 0.421 \\
\hline Constant & $\begin{array}{l}14.24 \\
(1.35)\end{array}$ & $\begin{array}{l}15.92 \\
(1.63)\end{array}$ & $\begin{array}{l}2.073 \\
(0.55)\end{array}$ & $\begin{array}{l}10.58 \\
(1.31)\end{array}$ & $\begin{array}{l}12.75 \\
(1.18)\end{array}$ \\
\hline Lags for IV & $6-7$ & $6-7$ & $6-7$ & $6-7$ & $6-7$ \\
\hline Observations & Yes & Yes & Yes & Yes & Yes \\
\hline Observations & 29,780 & 29,780 & 29,780 & 29,780 & 29,780 \\
\hline
\end{tabular}

$t$ statistics in parentheses

${ }^{*} p<0.05,{ }^{* *} p<0.01,{ }^{* * *} p<0.001$ 
Table 8: Alternatice definitions of wealth-financial wealth

\begin{tabular}{|c|c|c|c|c|c|}
\hline & $(1)$ & $(2)$ & $(3)$ & $(4)$ & $(5)$ \\
\hline $\log \left(\right.$ wealth $\left._{t-1}\right)$ & $\begin{array}{c}0.450^{*} \\
(1.99)\end{array}$ & $\begin{array}{l}0.338 \\
(1.45)\end{array}$ & $\begin{array}{l}0.355 \\
(1.75)\end{array}$ & $\begin{array}{l}0.498^{*} \\
(2.25)\end{array}$ & $\begin{array}{l}0.490^{*} \\
(2.15)\end{array}$ \\
\hline $\log \left(\right.$ wealth $\left._{t-2}\right)$ & $\begin{array}{c}0.0435 \\
(0.14)\end{array}$ & $\begin{array}{l}-0.111 \\
(-0.35)\end{array}$ & $\begin{array}{l}0.150 \\
(0.56)\end{array}$ & $\begin{array}{c}0.0614 \\
(0.21)\end{array}$ & $\begin{array}{l}0.207 \\
(0.75)\end{array}$ \\
\hline $\log \left(\right.$ wealth $\left._{t-3}\right)$ & $\begin{array}{l}-0.587 \\
(-1.67)\end{array}$ & $\begin{array}{c}-0.682^{*} \\
(-2.10)\end{array}$ & $\begin{array}{l}-0.447 \\
(-1.45)\end{array}$ & $\begin{array}{l}-0.468 \\
(-1.29)\end{array}$ & $\begin{array}{l}0.289 \\
(1.32)\end{array}$ \\
\hline $\log \left(\right.$ wealth $\left._{t-4}\right)$ & $\begin{array}{l}0.337 \\
(1.36)\end{array}$ & $\begin{array}{l}0.188 \\
(0.69)\end{array}$ & $\begin{array}{l}0.366 \\
(1.66)\end{array}$ & $\begin{array}{l}0.325 \\
(1.40)\end{array}$ & $\begin{array}{r}-0.352^{*} \\
(-2.09)\end{array}$ \\
\hline frailty & $\begin{array}{c}-4.283^{*} \\
(-2.28)\end{array}$ & & & & \\
\hline frailty $\times$ old & & $\begin{array}{c}-4.105^{*} \\
(-2.21)\end{array}$ & & & \\
\hline frailty $\times$ young & & $\begin{array}{l}-4.514 \\
(-1.64)\end{array}$ & & & \\
\hline frailty $\times$ college & & & $\begin{array}{l}-3.244 \\
(-1.72)\end{array}$ & & \\
\hline frailty $\times$ no college & & & $\begin{array}{c}-5.227^{* * *} \\
(-3.34)\end{array}$ & & \\
\hline frailty $\times$ good health & & & & $\begin{array}{l}0.129 \\
(0.03)\end{array}$ & \\
\hline frailty $\times$ bad health & & & & $\begin{array}{l}-3.186 \\
(-1.66)\end{array}$ & \\
\hline frailty $\times$ retired & & & & & $\begin{array}{c}-0.0854 \\
(-0.05)\end{array}$ \\
\hline frailty $\times$ not retired & & & & & $\begin{array}{l}3.186 \\
(0.94)\end{array}$ \\
\hline $\operatorname{AR}(1)$ test (p-value) & 0.004 & 0.010 & 0.010 & 0.003 & 0.000 \\
\hline $\operatorname{AR}(2)$ test (p-value) & 0.339 & 0.436 & 0.370 & 0.393 & 0.864 \\
\hline Hansen test of over-identification ( $\mathrm{p}$-value) & 0.372 & 0.501 & 0.358 & 0.436 & 0.266 \\
\hline Diff-in-Hansen test of exogeneity (p-value) & 0.228 & 0.388 & 0.514 & 0.359 & 0.207 \\
\hline Constant & $\begin{array}{l}6.958 \\
(0.55)\end{array}$ & $\begin{array}{l}7.180 \\
(0.45)\end{array}$ & $\begin{array}{l}13.23 \\
(1.44)\end{array}$ & $\begin{array}{l}6.862 \\
(0.59)\end{array}$ & $\begin{array}{l}7.469 \\
(0.52)\end{array}$ \\
\hline Lags for IV & 7 & 7 & 7 & 7 & 7 \\
\hline Observations & Yes & Yes & Yes & Yes & Yes \\
\hline Observations & 22,046 & 22,046 & 22,046 & 22,046 & 22,046 \\
\hline
\end{tabular}

$t$ statistics in parentheses

${ }^{*} p<0.05,{ }^{* *} p<0.01,{ }^{* * *} p<0.001$ 
Table 9: Alternatice definitions of wealth-housing wealth

\begin{tabular}{|c|c|c|c|c|c|}
\hline & $(1)$ & $(2)$ & $(3)$ & $(4)$ & $(5)$ \\
\hline $\log \left(\right.$ wealth $\left._{t-1}\right)$ & $\begin{array}{l}0.278 \\
(1.45)\end{array}$ & $\begin{array}{l}0.190 \\
(0.98)\end{array}$ & $\begin{array}{l}0.344 \\
(1.90)\end{array}$ & $\begin{array}{l}0.309 \\
(1.61)\end{array}$ & $\begin{array}{l}0.306 \\
(1.60)\end{array}$ \\
\hline $\log \left(\right.$ wealth $\left._{t-2}\right)$ & $\begin{array}{c}0.0441 \\
(0.25)\end{array}$ & $\begin{array}{c}0.0518 \\
(0.35)\end{array}$ & $\begin{array}{c}0.0768 \\
(0.49)\end{array}$ & $\begin{array}{c}0.0290 \\
(0.16)\end{array}$ & $\begin{array}{l}0.151 \\
(0.93)\end{array}$ \\
\hline $\log \left(\right.$ wealth $\left._{t-3}\right)$ & $\begin{array}{c}0.377^{*} \\
(2.17)\end{array}$ & $\begin{array}{l}0.287 \\
(1.86)\end{array}$ & $\begin{array}{l}0.288 \\
(1.88)\end{array}$ & $\begin{array}{l}0.385^{*} \\
(2.28)\end{array}$ & $\begin{array}{c}0.349^{*} \\
(2.01)\end{array}$ \\
\hline $\log \left(\right.$ wealth $\left._{t-4}\right)$ & $\begin{array}{l}0.170 \\
(1.22)\end{array}$ & $\begin{array}{l}0.249 \\
(1.94)\end{array}$ & $\begin{array}{c}0.0901 \\
(0.61)\end{array}$ & $\begin{array}{l}0.195 \\
(1.51)\end{array}$ & $\begin{array}{l}0.157 \\
(1.17)\end{array}$ \\
\hline frailty & $\begin{array}{c}-0.882^{* *} \\
(-2.96)\end{array}$ & & & & \\
\hline frailty $\times$ old & & $\begin{array}{c}-0.568^{*} \\
(-2.44)\end{array}$ & & & \\
\hline frailty $\times$ young & & $\begin{array}{l}-0.895 \\
(-1.73)\end{array}$ & & & \\
\hline frailty $\times$ college & & & $\begin{array}{c}-0.0446 \\
(-0.10)\end{array}$ & & \\
\hline frailty $\times$ no college & & & $\begin{array}{c}-0.717^{* *} \\
(-3.24)\end{array}$ & & \\
\hline frailty $\times$ good health & & & & $\begin{array}{l}-1.594 \\
(-1.31)\end{array}$ & \\
\hline frailty $\times$ bad health & & & & $\begin{array}{c}-1.088^{* *} \\
(-2.73)\end{array}$ & \\
\hline frailty $\times$ retired & & & & & $\begin{array}{c}-0.942^{*} \\
(-2.26)\end{array}$ \\
\hline frailty $\times$ not retired & & & & & $\begin{array}{l}0.404 \\
(0.37)\end{array}$ \\
\hline $\operatorname{AR}(1)$ test ( $p$-value) & 0.047 & 0.057 & 0.022 & 0.038 & 0.035 \\
\hline $\operatorname{AR}(2)$ test ( $p$-value $)$ & 0.506 & 0.701 & 0.558 & 0.463 & 0.725 \\
\hline Hansen test of over-identification (p-value) & 0.711 & 0.434 & 0.352 & 0.811 & 0.880 \\
\hline Diff-in-Hansen test of exogeneity (p-value) & 0.819 & 0.583 & 0.484 & 0.795 & 0.696 \\
\hline Constant & $\begin{array}{l}4.347 \\
(1.38)\end{array}$ & $\begin{array}{l}2.299 \\
(0.71)\end{array}$ & $\begin{array}{l}2.484 \\
(1.16)\end{array}$ & $\begin{array}{l}4.324 \\
(1.30)\end{array}$ & $\begin{array}{l}3.385 \\
(0.83)\end{array}$ \\
\hline Lags for IV & $6-7$ & $6-7$ & $6-7$ & $6-7$ & $6-7$ \\
\hline Observations & Yes & Yes & Yes & Yes & Yes \\
\hline Observations & 29,031 & 29,031 & 29,031 & 29,031 & 29,031 \\
\hline
\end{tabular}

$t$ statistics in parentheses

${ }^{*} p<0.05,{ }^{* *} p<0.01,{ }^{* * *} p<0.001$ 


\section{Conclusion}

In this paper I document the empirical relationship between health and wealth. May main contribution is that I am able to empirically evaluate the overall marginal impact of suffering from one more health deficit on household wealth. Analysis shows that suffering one more health deficit leads to a 2.45 percent reduction of household net worth. In particular, the individuals without college degree and the elderly suffer the biggest wealth loss due to poor health. Using dynamic panel data approach and a new measure of health (frailty index), I find that the impact of poor health among the retirees is significant, while it is insignificant among the non-retirees. This paper also contributes to the literature by rigorously accounting for the dynamic relationship between health, wealth, and other socioeconomic factors in the analysis of the impact of health on wealth. The results remain robust across several alternative definitions of wealth. Results show that the impact of bad health is largest on financial wealth and smallest on housing wealth. A number of empirical tests confirm the validity of the instruments used in the analysis. One of the limitations of this study is that the data includes only the individuals of age 50 to 100. Empirical evaluation of impact of health on wealth over the entire life-cycle is left for future research. 


\section{References}

Arellano, Manuel, and Stephen Bond. 1991. "Some tests of specification for panel data: Monte Carlo evidence and an application to employment equations." The review of economic studies 58 (2): 277-297.

Arellano, Manuel, and Olympia Bover. 1995. "Another look at the instrumental variable estimation of error-components models." Journal of econometrics 68 (1): 29-51.

Blundell, Richard, and Stephen Bond. 1998. "Initial conditions and moment restrictions in dynamic panel data models." Journal of econometrics 87 (1): 115-143.

Bond, Stephen R. 2002b. "Dynamic panel data models: a guide to micro data methods and practice." Portuguese economic journal 1 (2): 141-162.

Coile, Courtney, and Kevin Milligan. 2009. "How household portfolios evolve after retirement: The effect of aging and health shocks." Review of Income and Wealth 55 (2): $226-248$.

De Nardi, Mariacristina, Eric French, and John B Jones. 2010. "Why do the elderly save? The role of medical expenses." Journal of political economy 118 (1): 39-75.

De Nardi, Mariacristina, Svetlana Pashchenko, and Ponpoje Porapakkarm. 2017. The lifetime costs of bad health. Technical report. National Bureau of Economic Research.

Eichenbaum, Martin S, Lars Peter Hansen, and Kenneth J Singleton. 1988. "A time series analysis of representative agent models of consumption and leisure choice under uncertainty." The Quarterly Journal of Economics 103 (1): 51-78.

Holtz-Eakin, Douglas, Whitney Newey, and Harvey S Rosen. 1988. "Estimating vector autoregressions with panel data." Econometrica: Journal of the econometric society: 13711395.

Hosseini, Roozbeh, Karen Kopecky, and Kai Zhao. 2019a. "The evolution of health over the life cycle." FRB Atlanta Working Paper.

. 2019b. "How Important Is Health Inequality for Lifetime Earnings Inequality?" Unpublished Manuscript.

Hurd, Michael D, Erik Meijer, Michael Moldoff, and Susann Rohwedder. 2016. "Improved wealth measures in the Health and Retirement Study: asset reconciliation and cross-wave imputation."

Kopecky, Karen A, and Tatyana Koreshkova. 2014. "The impact of medical and nursing home expenses on savings." American Economic Journal: Macroeconomics 6 (3): 29-72.

Lockwood, Lee M. 2018. "Incidental bequests and the choice to self-insure late-life risks." American Economic Review 108 (9): 2513-50. 
Nakajima, Makoto, Irina A Telyukova, et al. 2018. "Medical expenses and saving in retirement: The case of US and Sweden." Federal Reserve Bank of Minneapolis Opportunity and Inclusive Growth Institute Working Paper 8.

Nickell, Stephen. 1981. "Biases in dynamic models with fixed effects." Econometrica: Journal of the econometric society: 1417-1426.

Palumbo, Michael G. 1999. "Uncertain medical expenses and precautionary saving near the end of the life cycle." The Review of Economic Studies 66 (2): 395-421.

Poterba, James M, Steven F Venti, and David A Wise. 2011. "Family status transitions, latent health, and the post-retirement evolution of assets." In Explorations in the Economics of Aging, 23-69. University of Chicago Press.

Rohwedder, Susann, Steven J Haider, and Michael D Hurd. 2006. "Increases in wealth among the elderly in the early 1990s: How much is due to survey design?" Review of Income and Wealth 52 (4): 509-524.

Roodman, David. 2009. "How to do xtabond2: An introduction to difference and system GMM in Stata." The stata journal 9 (1): 86-136.

Smith, James P. 1999. "Healthy bodies and thick wallets: the dual relation between health and economic status." Journal of Economic perspectives 13 (2): 145-166.

. 2004. "Unraveling the SES: health connection." Population and development review 30:108-132.

Wallace, Geoffrey L, Robert Haveman, Karen Holden, and Barbara Wolfe. 2012. "Health and wealth in early retirement." The Australian National University Centre for Economic Policy Research Discussion Paper No. 669.

Wallace, Geoffrey L, Robert Haveman, and Barbara Wolfe. 2017. "Health status, health shocks, and asset adequacy over retirement years." Research on aging 39 (1): 222-248.

Wintoki, M Babajide, James S Linck, and Jeffry M Netter. 2012. "Endogeneity and the dynamics of internal corporate governance." Journal of financial economics 105 (3): 581-606.

Wu, Stephen. 2003. "The effects of health events on the economic status of married couples." Journal of Human Resources 38 (1): 219-230.

Zhao, Kai. 2014. "Social security and the rise in health spending." Journal of Monetary Economics 64:21-37.

. 2015. "The impact of the correlation between health expenditure and survival probability on the demand for insurance." European Economic Review 75:98-111. 


\section{Appendix A: Health variables used in the frailty index}

\begin{tabular}{|c|c|c|}
\hline S.No. & Health variables & Score \\
\hline & Has the doctor ever told you that you have: & \\
\hline 1 & High blood pressure & $Y e s=1, N_{o}=0$ \\
\hline 2 & Diabetes & $Y e s=1, N o=0$ \\
\hline 3 & Cancer or a malignant tumor of any kind except skin cancer & $Y e s=1, N o=0$ \\
\hline 4 & $\begin{array}{l}\text { Chronic lung disease except asthma such as chronic bron- } \\
\text { chitis or emphysema }\end{array}$ & $Y e s=1, N o=0$ \\
\hline 5 & $\begin{array}{l}\text { Heart attack, coronary heart disease, angina, congestive } \\
\text { heart failure, or other heart problems }\end{array}$ & $Y e s=1, N o=0$ \\
\hline 6 & Stroke or transient ischemic attack (TIA) & $Y e s=1, N o=0$ \\
\hline 7 & Emotional, nervous, or psychiatric problems & $Y e s=1, N o=0$ \\
\hline \multirow[t]{2}{*}{8} & Arthritis or rheumatism & $Y e s=1, N_{o}=0$ \\
\hline & $\begin{array}{l}\text { Do you have some difficulty with the following } \\
\text { ADLs: }\end{array}$ & \\
\hline 9 & Bathing & $Y e s=1, N o=0$ \\
\hline 10 & Dressing & $Y e s=1, N o=0$ \\
\hline 11 & Eating & $Y e s=1, N o=0$ \\
\hline 12 & Getting in/out of bed & $Y e s=1, N o=0$ \\
\hline 13 & Walking across room & $Y e s=1, N o=0$ \\
\hline \multirow[t]{2}{*}{14} & using toilet & $Y e s=1, N_{o}=0$ \\
\hline & $\begin{array}{l}\text { Do you have some difficulty with the following } \\
\text { IADLs: }\end{array}$ & \\
\hline 15 & Using a phone & $Y e s=1, N o=0$ \\
\hline 16 & Managing money & $Y e s=1, N o=0$ \\
\hline 17 & Taking medications & $Y e s=1, N_{o}=0$ \\
\hline 18 & Shopping for groceries & $Y e s=1, N o=0$ \\
\hline 19 & Preparing a hot meal & $Y e s=1, N o=0$ \\
\hline 20 & Walking several blocks & $Y e s=1, N o=0$ \\
\hline 21 & Climbing one flat stair & $Y e s=1, N o=0$ \\
\hline 22 & Sitting for two hours & $Y e s=1, N o=0$ \\
\hline 23 & Getting up from chair & $Y e s=1, N o=0$ \\
\hline 24 & Stooping/kneeling/crutching & $Y e s=1, N o=0$ \\
\hline 25 & Pushing/pulling a large object & $Y e s=1, N o=0$ \\
\hline 26 & Picking up a dime & $Y e s=1, N o=0$ \\
\hline 27 & Lifting/carrying 10lbs & $Y e s=1, N o=0$ \\
\hline \multirow[t]{2}{*}{28} & Extending arms & $Y e s=1, N o=0$ \\
\hline & Cognitive health: & \\
\hline 29 & Immediate word recall & 0.1 for each word not recalled \\
\hline 30 & Delayed word recall & 0.1 for each word not recalled \\
\hline 31 & Serial 7 test & 0.2 for each word not recalled \\
\hline 32 & Backward counting & $\begin{array}{l}\text { Failed }=1,2 \text { nd attempt }=0.5, \\
1 \text { st attempt }=0\end{array}$ \\
\hline 33 & Identifying objects (four objects in total) & 0.25 for a wrong answer \\
\hline 34 & Date naming (month, date, day, and year) & 0.25 for a wrong answer \\
\hline 35 & Ever smoked? & $Y e s=1, N o=0$ \\
\hline 36 & $\mathrm{BMI} \geq 30 ?$ & $Y e s=1, N_{o}=0$ \\
\hline
\end{tabular}




\section{Appendix B: Experiment with different IV lags}

Since the first four lags of wealth are used as independent variables in the model specification, I can only choose the instruments from lag 5 to lag 7 of the endogenous variables. In this section, I experiment with different lags and choose the lags that best satisfy the tradeoff between the endogeneity problem and the weak IV problem. If I use deeper lags, the IVs may lose explanatory power (weak IV problem) while the potential correlation between the error and regressors is reduced, strengthening the exogeneity of IVs at the expense of their strength. On the other hand, if I use recent lags, I could address the weak IV problem at the expense of greater endogeneity. In Table 11. I observe that using lag 5-6 and 5-7 leads to one or another problem. With both lags, endogeneity seems to be the major problem. For example, when using lags 5-6, I pass the AR(2) test but fail the Hansen test of over-identification as well as the Diff-in-Hansen test of exogeneity of instruments. When using the lags 5-7, the

results fail even the $\operatorname{AR}(2)$ test. This forces us to use deeper lags as instruments. In column (2), I go a lag deeper and pass the AR(2) test, Hansen test of over-identification, and the Diff-in-Hansen test of exogeneity of instruments. 
Table 11: Experiment with different IV Lags

\begin{tabular}{lccc}
\hline & $5-6$ & $6-7$ & $5-7$ \\
\hline $\log \left(\right.$ wealth $\left._{t-1}\right)$ & 0.563 & 0.248 & 0.162 \\
& $(1.54)$ & $(1.02)$ & $(0.52)$ \\
$\log \left(\right.$ wealth $\left._{t-2}\right)$ & 0.281 & $0.463^{*}$ & $0.537^{*}$ \\
& $(0.77)$ & $(2.05)$ & $(2.22)$ \\
$\log \left(\right.$ wealth $\left._{t-3}\right)$ & 0.199 & -0.134 & 0.127 \\
& $(1.09)$ & $(-0.65)$ & $(0.79)$ \\
$\log ($ wealth & \\
& -0.0498 & 0.317 & -0.0120 \\
frailty & $(-0.97)$ & $(1.88)$ & $(-0.22)$ \\
& $-0.659^{*}$ & $-2.143^{* * *}$ & $-0.905^{*}$ \\
AR(1) test (p-value) & $(-2.12)$ & $(-3.57)$ & $(-2.41)$ \\
AR(2) test (p-value) & & & \\
Hansen test of over-identification (p-value) & 0.042 & 0.563 & 0.043 \\
Diff-in-Hansen test of exogeneity (p-value) & 0.002 & 0.476 & 0.004 \\
Constant & 0.179 & 0.025 & 0.284 \\
& 0.777 & 11.56 & -1.445 \\
& $(0.17)$ & $(1.74)$ & $(-0.24)$ \\
\hline Number of instruments & 40 & 40 & 44 \\
Controls & Yes & Yes & Yes \\
Observations & 32,880 & 32,880 & 32,880 \\
\hline$t$ statisics & & &
\end{tabular}

$t$ statistics in parentheses

${ }^{*} p<0.05,{ }^{* *} p<0.01,{ }^{* * *} p<0.001$

Control variables are education, total household earnings, year dummies, marital status, number of alive siblings, family size, cubic polynomial in age, and a dummy for long term care insurance. Frailty and household income, and long-term care insurance status are treated as endogenous variables. Education, number of siblings, and family size are treated as predetermined variables. All other variables are treated as strictly exogenous. All the exogenous variables are used only in level equations. These are two-step GMM estimates with robust standard errors and forward orthogonal deviations (FOD) with collapsed instrument matrix. Regressions are run (using David Roodman's xtabond2 Stata package for Dynamic Panel Data). 
Table 12: Experiment with different IV Lags, by age group

\begin{tabular}{|c|c|c|c|}
\hline & $5-6$ & $6-7$ & $5-7$ \\
\hline $\log \left(\right.$ wealth $\left._{t-1}\right)$ & $\begin{array}{c}0.733^{* *} \\
(2.62)\end{array}$ & $\begin{array}{c}0.625^{* *} \\
(2.79)\end{array}$ & $\begin{array}{l}0.442 \\
(1.67)\end{array}$ \\
\hline $\log \left(\right.$ wealth $\left._{t-2}\right)$ & $\begin{array}{c}0.0870 \\
(0.28)\end{array}$ & $\begin{array}{l}0.294 \\
(1.25)\end{array}$ & $\begin{array}{l}0.382 \\
(1.51)\end{array}$ \\
\hline $\log \left(\right.$ wealth $\left._{t-3}\right)$ & $\begin{array}{l}0.145 \\
(0.75)\end{array}$ & $\begin{array}{l}-0.325 \\
(-1.62)\end{array}$ & $\begin{array}{c}0.0166 \\
(0.09)\end{array}$ \\
\hline $\log \left(\right.$ wealth $\left._{t-4}\right)$ & $\begin{array}{c}-0.0290 \\
(-0.54)\end{array}$ & $\begin{array}{l}0.278 \\
(1.64)\end{array}$ & $\begin{array}{c}0.00705 \\
(0.13)\end{array}$ \\
\hline frailty $\times$ old & $\begin{array}{c}-0.622^{*} \\
(-2.10)\end{array}$ & $\begin{array}{c}-1.672^{* *} \\
(-3.18)\end{array}$ & $\begin{array}{c}-0.681^{*} \\
(-2.02)\end{array}$ \\
\hline frailty $\times$ young & $\begin{array}{c}0.0270 \\
(0.04)\end{array}$ & $\begin{array}{l}-0.515 \\
(-0.62)\end{array}$ & $\begin{array}{l}-0.121 \\
(-0.17)\end{array}$ \\
\hline $\begin{array}{l}\operatorname{AR}(1) \text { test ( } p \text {-value) } \\
\operatorname{AR}(2) \text { test ( } p \text {-value) } \\
\text { Hansen test of over-identification ( } p \text {-value) } \\
\text { Diff-in-Hansen test of exogeneity ( } p \text {-value) }\end{array}$ & $\begin{array}{l}0.040 \\
0.641 \\
0.107 \\
0.006\end{array}$ & $\begin{array}{l}0.007 \\
0.347 \\
0.362 \\
0.159\end{array}$ & $\begin{array}{l}0.104 \\
0.422 \\
0.046 \\
0.021\end{array}$ \\
\hline Constant & $\begin{array}{l}1.098 \\
(0.26)\end{array}$ & $\begin{array}{l}10.69 \\
(1.73)\end{array}$ & $\begin{array}{l}0.697 \\
(0.13)\end{array}$ \\
\hline $\begin{array}{l}\text { Number of instruments } \\
\text { Controls } \\
\text { Observations }\end{array}$ & $\begin{array}{c}43 \\
\text { Yes } \\
32,880\end{array}$ & $\begin{array}{c}43 \\
\text { Yes } \\
32,880\end{array}$ & $\begin{array}{c}48 \\
\text { Yes } \\
32,880\end{array}$ \\
\hline
\end{tabular}

$t$ statistics in parentheses

${ }^{*} p<0.05,{ }^{* *} p<0.01,{ }^{* * *} p<0.001$

Control variables are education, total household earnings, year dummies, marital status, number of alive siblings, family size, cubic polynomial in age, and a dummy for long term care insurance. Frailty and household income, and long-term care insurance status are treated as endogenous variables. Education, number of siblings, and family size are treated as predetermined variables. All other variables are treated as strictly exogenous. All the exogenous variables are used only in level equations. These are two-step GMM estimates with robust standard errors and forward orthogonal deviations (FOD) with collapsed instrument matrix. Regressions are run (using David Roodman's xtabond2 Stata package for Dynamic Panel Data). 
Table 13: Experiment with different IV Lags, by education

\begin{tabular}{|c|c|c|c|}
\hline & $5-6$ & $6-7$ & $5-7$ \\
\hline $\log \left(\right.$ wealth $\left._{t-1}\right)$ & $\begin{array}{l}0.699^{*} \\
(2.33)\end{array}$ & $\begin{array}{l}0.380 \\
(1.66)\end{array}$ & $\begin{array}{l}0.523^{*} \\
(2.06)\end{array}$ \\
\hline $\log \left(\right.$ wealth $\left._{t-2}\right)$ & $\begin{array}{l}0.252 \\
(0.66)\end{array}$ & $\begin{array}{l}0.463^{*} \\
(2.03)\end{array}$ & $\begin{array}{l}0.478 \\
(1.70)\end{array}$ \\
\hline $\log \left(\right.$ wealth $\left._{t-3}\right)$ & $\begin{array}{l}0.147 \\
(0.73)\end{array}$ & $\begin{array}{l}-0.222 \\
(-1.11)\end{array}$ & $\begin{array}{c}0.0650 \\
(0.35)\end{array}$ \\
\hline $\log \left(\right.$ wealth $\left._{t-4}\right)$ & $\begin{array}{r}-0.0447 \\
(-0.91)\end{array}$ & $\begin{array}{l}0.253 \\
(1.65)\end{array}$ & $\begin{array}{c}-0.0315 \\
(-0.67)\end{array}$ \\
\hline frailty $\times$ college & $\begin{array}{c}0.0344 \\
(0.07)\end{array}$ & $\begin{array}{l}-0.881 \\
(-1.60)\end{array}$ & $\begin{array}{c}-0.0752 \\
(-0.16)\end{array}$ \\
\hline frailty $\times$ no college & $\begin{array}{c}-0.792^{* *} \\
(-2.64)\end{array}$ & $\begin{array}{c}-1.603^{* * *} \\
(-3.98)\end{array}$ & $\begin{array}{c}-0.928^{* *} \\
(-3.06)\end{array}$ \\
\hline $\begin{array}{l}\operatorname{AR}(1) \text { test ( } p \text {-value) } \\
\operatorname{AR}(2) \text { test ( } p \text {-value) } \\
\text { Hansen test of over-identification ( } p \text {-value) } \\
\text { Diff-in-Hansen test of exogeneity ( } p \text {-value) }\end{array}$ & $\begin{array}{l}0.120 \\
0.959 \\
0.084 \\
0.005\end{array}$ & $\begin{array}{l}0.027 \\
0.208 \\
0.254 \\
0.145\end{array}$ & $\begin{array}{l}0.132 \\
0.379 \\
0.023 \\
0.001\end{array}$ \\
\hline Constant & $\begin{array}{l}2.574 \\
(0.93)\end{array}$ & $\begin{array}{l}3.211 \\
(0.99)\end{array}$ & $\begin{array}{l}3.003 \\
(1.05)\end{array}$ \\
\hline $\begin{array}{l}\text { Number of instruments } \\
\text { Controls } \\
\text { Observations }\end{array}$ & $\begin{array}{c}43 \\
\text { Yes } \\
32,880\end{array}$ & $\begin{array}{c}43 \\
\text { Yes } \\
32,880\end{array}$ & $\begin{array}{c}48 \\
\text { Yes } \\
32,880\end{array}$ \\
\hline
\end{tabular}

$t$ statistics in parentheses

${ }^{*} p<0.05,{ }^{* *} p<0.01,{ }^{* * *} p<0.001$

Control variables are education, total household earnings, year dummies, marital status, number of alive siblings, family size, cubic polynomial in age, and a dummy for long term care insurance. Frailty and household income, and long-term care insurance status are treated as endogenous variables. Education, number of siblings, and family size are treated as predetermined variables. All other variables are treated as strictly exogenous. All the exogenous variables are used only in level equations. These are two-step GMM estimates with robust standard errors and forward orthogonal deviations (FOD) with collapsed instrument matrix. Regressions are run (using David Roodman's xtabond2 Stata package for Dynamic Panel Data). 
Table 14: Experiment with different IV Lags, by health

\begin{tabular}{|c|c|c|c|}
\hline & $5-6$ & $6-7$ & $5-7$ \\
\hline $\log \left(\right.$ wealth $\left._{t-1}\right)$ & $\begin{array}{l}0.508 \\
(1.39)\end{array}$ & $\begin{array}{l}0.242 \\
(1.07)\end{array}$ & $\begin{array}{l}0.271 \\
(0.98)\end{array}$ \\
\hline $\log \left(\right.$ wealth $\left._{t-2}\right)$ & $\begin{array}{l}0.374 \\
(1.05)\end{array}$ & $\begin{array}{c}0.485^{*} \\
(2.27)\end{array}$ & $\begin{array}{l}0.497^{*} \\
(2.14)\end{array}$ \\
\hline $\log \left(\right.$ wealth $\left._{t-3}\right)$ & $\begin{array}{l}0.167 \\
(0.88)\end{array}$ & $\begin{array}{l}-0.109 \\
(-0.55)\end{array}$ & $\begin{array}{c}0.0908 \\
(0.52)\end{array}$ \\
\hline $\log \left(\right.$ wealth $\left._{t-4}\right)$ & $\begin{array}{c}-0.0501 \\
(-0.93)\end{array}$ & $\begin{array}{l}0.297 \\
(1.82)\end{array}$ & $\begin{array}{c}-0.0106 \\
(-0.20)\end{array}$ \\
\hline frailty $\times$ good health & $\begin{array}{l}-0.388 \\
(-0.35)\end{array}$ & $\begin{array}{l}-2.761 \\
(-1.18)\end{array}$ & $\begin{array}{l}-0.417 \\
(-0.35)\end{array}$ \\
\hline frailty $\times$ bad health & $\begin{array}{l}-0.611 \\
(-1.74)\end{array}$ & $\begin{array}{c}-2.055^{* *} \\
(-2.68)\end{array}$ & $\begin{array}{l}-0.774 \\
(-1.95)\end{array}$ \\
\hline $\begin{array}{l}\operatorname{AR}(1) \text { test ( } \mathrm{p} \text {-value) } \\
\operatorname{AR}(2) \text { test ( } \mathrm{p} \text {-value) } \\
\text { Hansen test of over-identification ( } \mathrm{p} \text {-value) } \\
\text { Diff-in-Hansen test of exogeneity ( } \mathrm{p} \text {-value) }\end{array}$ & $\begin{array}{l}0.228 \\
0.716 \\
0.058 \\
0.004\end{array}$ & $\begin{array}{l}0.019 \\
0.182 \\
0.438 \\
0.432\end{array}$ & $\begin{array}{l}0.175 \\
0.152 \\
0.049 \\
0.007\end{array}$ \\
\hline Constant & $\begin{array}{l}0.802 \\
(0.16)\end{array}$ & $\begin{array}{l}9.226 \\
(1.52)\end{array}$ & $\begin{array}{l}-0.489 \\
(-0.09)\end{array}$ \\
\hline $\begin{array}{l}\text { Number of instruments } \\
\text { Controls } \\
\text { Observations }\end{array}$ & $\begin{array}{c}43 \\
\text { Yes } \\
32,880\end{array}$ & $\begin{array}{c}43 \\
\text { Yes } \\
32,880\end{array}$ & $\begin{array}{c}48 \\
\text { Yes } \\
32,880\end{array}$ \\
\hline
\end{tabular}

$t$ statistics in parentheses

${ }^{*} p<0.05,{ }^{* *} p<0.01,{ }^{* * *} p<0.001$

Control variables are education, total household earnings, year dummies, marital status, number of alive siblings, family size, cubic polynomial in age, and a dummy for long term care insurance. Frailty and household income, and long-term care insurance status are treated as endogenous variables. Education, number of siblings, and family size are treated as predetermined variables. All other variables are treated as strictly exogenous. All the exogenous variables are used only in level equations. These are two-step GMM estimates with robust standard errors and forward orthogonal deviations (FOD) with collapsed instrument matrix. Regressions are run (using David Roodman's xtabond2 Stata package for Dynamic Panel Data). 
Table 15: Experiment with different IV Lags, by retirement status

\begin{tabular}{|c|c|c|c|}
\hline & $5-6$ & $6-7$ & $5-7$ \\
\hline $\log \left(\right.$ wealth $\left._{t-1}\right)$ & $\begin{array}{c}1.114^{* * *} \\
(3.52)\end{array}$ & $\begin{array}{l}0.317 \\
(1.08)\end{array}$ & $\begin{array}{l}0.848^{*} \\
(2.54)\end{array}$ \\
\hline $\log \left(\right.$ wealth $\left._{t-2}\right)$ & $\begin{array}{l}-0.183 \\
(-0.46)\end{array}$ & $\begin{array}{l}0.468 \\
(1.83)\end{array}$ & $\begin{array}{c}0.0666 \\
(0.22)\end{array}$ \\
\hline $\log \left(\right.$ wealth $\left._{t-3}\right)$ & $\begin{array}{l}0.142 \\
(0.57)\end{array}$ & $\begin{array}{l}-0.162 \\
(-0.69)\end{array}$ & $\begin{array}{c}0.0140 \\
(0.07)\end{array}$ \\
\hline $\log \left(\right.$ wealth $\left._{t-4}\right)$ & $\begin{array}{c}-0.0116 \\
(-0.19)\end{array}$ & $\begin{array}{l}0.279 \\
(1.69)\end{array}$ & $\begin{array}{c}0.00930 \\
(0.18)\end{array}$ \\
\hline frailty $\times$ retired & $\begin{array}{l}-0.602 \\
(-1.21)\end{array}$ & $\begin{array}{c}-2.159^{* *} \\
(-3.06)\end{array}$ & $\begin{array}{l}-0.594 \\
(-1.64)\end{array}$ \\
\hline frailty $\times$ not retired & $\begin{array}{l}-0.480 \\
(-0.32)\end{array}$ & $\begin{array}{l}-1.678 \\
(-0.97)\end{array}$ & $\begin{array}{l}-0.109 \\
(-0.09)\end{array}$ \\
\hline $\begin{array}{l}\operatorname{AR}(1) \text { test ( } p \text {-value) } \\
\operatorname{AR}(2) \text { test ( } p \text {-value) } \\
\text { Hansen test of over-identification ( } p \text {-value) } \\
\text { Diff-in-Hansen test of exogeneity ( } p \text {-value) }\end{array}$ & $\begin{array}{l}0.019 \\
0.306 \\
0.434 \\
0.020\end{array}$ & $\begin{array}{l}0.044 \\
0.263 \\
0.681 \\
0.522\end{array}$ & $\begin{array}{l}0.041 \\
0.707 \\
0.016 \\
0.000\end{array}$ \\
\hline Constant & $\begin{array}{l}6.393 \\
(0.70)\end{array}$ & $\begin{array}{l}13.50 \\
(1.74)\end{array}$ & $\begin{array}{l}1.483 \\
(0.28)\end{array}$ \\
\hline $\begin{array}{l}\text { Number of instruments } \\
\text { Controls } \\
\text { Observations }\end{array}$ & $\begin{array}{c}43 \\
\text { Yes } \\
32,880\end{array}$ & $\begin{array}{c}43 \\
\text { Yes } \\
32,880\end{array}$ & $\begin{array}{c}48 \\
\text { Yes } \\
32,880\end{array}$ \\
\hline
\end{tabular}

$t$ statistics in parentheses

${ }^{*} p<0.05,{ }^{* *} p<0.01,{ }^{* * *} p<0.001$

Control variables are education, total household earnings, year dummies, marital status, number of alive siblings, family size, cubic polynomial in age, and a dummy for long term care insurance. Frailty and household income, and long-term care insurance status are treated as endogenous variables. Education, number of siblings, and family size are treated as predetermined variables. All other variables are treated as strictly exogenous. All the exogenous variables are used only in level equations. These are two-step GMM estimates with robust standard errors and forward orthogonal deviations (FOD) with collapsed instrument matrix. Regressions are run (using David Roodman's xtabond2 Stata package for Dynamic Panel Data). 